\title{
Estimates of the Tempo-adjusted Total Fertility Rate in Western and Eastern Germany, 1955-2008
}

\author{
Marc Luy, Olga Pötzsch
}

\begin{abstract}
In this article we present estimates of the tempo-adjusted total fertility rate in Western and Eastern Germany from 1955 to 2008. Tempo adjustment of the total fertility rate (TFR) requires data on the annual number of births by parity and age of the mother. Since official statistics do not provide such data for West Germany as well as Eastern Germany from 1990 on we used alternative data sources which include these specific characteristics. The combined picture of conventional TFR and tempo-adjusted TFR* provides interesting information about the trends in period fertility in Western and Eastern Germany, above all with regard to the differences between the two regions and the enormous extent of tempo effects in Eastern Germany during the 1990s. Compared to corresponding data for populations from other countries, our estimates of the tempo-adjusted TFR* for Eastern and Western Germany show plausible trends. Nevertheless, it is important to note that the estimates of the tempo-adjusted total fertility rate presented in this paper should not be seen as being on the level of or equivalent to official statistics since they are based on different kinds of data with different degrees of quality.
\end{abstract}

Keywords: Germany $\cdot$ Fertility $\cdot$ Fertility trends $\cdot$ Tempo adjustment $\cdot$ Tempo-adjusted TFR $\cdot$ Bongaarts - Feeney $\cdot$ Total fertility rate $\cdot$ East-West comparison · Parity $\cdot$ Biological birth order $\cdot$ Average age at childbirth

\section{Introduction}

The East-West German differences in fertility trends which have been observed over many decades are probably the most frequently studied aspect of the demographic differences between Eastern and Western Germany. Above all the changes in Eastern German fertility have been frequently studied in recent years (e.g. Dorbritz 1992; Menning 1995; Witte/Wagner 1995; Conrad et al. 1996; Beck-Gernsheim 1997; Dorbritz 1997; Sackmann 1999; Lechner 2001; Sobotka 2002; Kreyenfeld 2003; Kreyenfeld 2009), and are regarded as the main characteristic of the "demographic shock" experienced by the population in the new Federal Länder after the 
political changes (Eberstadt 1994). The level of fertility and its changes over time are particularly important because they have the strongest long-term impact on the age structure of a population (Luy 2009). This is why the determinants of fertility and of childlessness in the context of the specific backgrounds of life in Western and Eastern Germany have been analysed intensively in recent years (e.g. Dorbritz/ Schwarz 1996; Hank 2002; Dornseiff/Sackmann 2003; Hank/Kreyenfeld 2003; Hank et al. 2004; Butterwege et al. 2005; Eckhard 2006; Boehnke 2007; Bernardi/Keim 2007; Bernardi et al. 2008; Arránz Becker et al. 2010; Pötzsch 2010).

For most politically and socially relevant questions the absolute numbers of births are of primary interest since these determine the future numbers of kindergarten children, school pupils, students, employed persons or pensioners, albeit the size of these population groups is additionally determined by mortality and migration. Demographic fertility research, by contrast, studies primarily the relative fertility quantum in order to be able to describe changes and differences between populations and to identify the corresponding determinants and influencing factors. The demographic indicator used most frequently in the field of period analysis - i.e. the analysis of fertility conditions in a specific calendar year - is the "total fertility rate" (TFR) which is often interpreted as the "average number of children". However, it is generally difficult in the period analysis to give a specific meaning to such measures. This is only possible in the cohort perspective, in which the fertility of a real cohort is analysed year by year on a longitudinal basis. Period analysis, by contrast, summarizes the fertility of a specific calendar year using the age-specific fertility rates of all women who were between 15 and 49 years old in this calendar year. By summing up the age-specific fertility rates to the total fertility rate, a hypothetical cohort is constructed which is supposed to represent the current fertility conditions (see Sobotka and Lutz 2010 on the problem of the use of the period TFR for questions of political and societal relevance).

The observed or reconstructed number of births of women belonging to a certain cohort can be influenced by specific period and cohort effects. In general, these effects are not seen as distortions, but rather as causal determinants of cohort fertility and are thus of central interest of the analysis. Period analysis, by contrast, aims to describe the "pure" fertility level of a specific calendar year- the so-called "quantum of fertility" - without including any other structural factors determining or influencing the level of fertility. A classical structural factor influencing the overall fertility level is the age composition of a population, which can have a major impact on the number of births. Thus, demographic period indicators such as the TFR are calculated as age-standardised measures. (Although cohort indicators are generally calculated age-standardised as well, no comparable distortion effects of the age composition can occur here).

At the end of the 1990s, Bongaarts and Feeney (1998) showed that changes in the average age at childbirth occurring during a calendar year alter fertility rates and hence the TFR, a phenomenon that has been described already by Hajnal (1947). Bongaarts and Feeney (1998) referred to this alteration of the TFR as a "tempo effect" and proposed to not only standardize the total fertility rate by age, but to also adjust the TFR for tempo effects. The basic idea of Bongaarts and Feeney is that 
tempo effects are also a structural factor distorting the TFR when this indicator is used to reflect the pure quantum of current fertility. An increase in the average age at childbirth during the analyzed calendar year leads to a tempo effect-caused reduction in the fertility rates, and a reduction in the average age at childbirth leads to a tempo effect-caused increase in the fertility rates. Even though the existence of such tempo effects in the period TFR is not questioned among demographers, opinions as to the need for the tempo adjustment diverge in some respects. Nonetheless, the additional use of the tempo-adjusted total fertility rate, which is symbolised by TFR* ${ }^{*}$, has more and more become the standard in demographic fertility research in recent years. This can be seen in the increasing number of publications in which fertility trends and differentials are analysed not only on the basis of the conventional TFR, but also using the TFR* (e.g. Lesthaeghe/Willems 1999; Philipov/ Kohler 2001; Goldstein et al. 2003; Sobotka 2003, 2004a, 2004b; Frejka/Sobotka 2008; Goldstein et al. 2009). The TFR* is also a part of the standard repertoire of demographic indices compiled in the "European Demographic Datasheet", published every two years by the Vienna Institute of Demography of the Austrian Academy of Sciences (available on the Internet at http://www.oeaw.ac.at/vid/datasheet/index. html).

In most of the above mentioned publications, however, information on the tempo-adjusted TFR* is missing for some European populations, including Germany. The calculation of the tempo-adjusted TFR* requires the number of births being separated not only by age of the mother but also by parity. This information was not available for unified Germany and for former West Germany until 2009 because of the statutory regulations. Prior to 2009 , the parity was exclusively collected for births of married mothers, with the birth order referring solely to children of the current marriage (including pre-maritial children with the current husband). Premaritial children with fathers other than the mother's current husband, as well as children from previous marriages, have not been considered and thus did not enter official population statistics on parity. Only after the supplement of the Population Statistics Act in 2009 (Bevölkerungsstatistikgesetz/Federal Law Gazette [BGB/] 2007) it was possible to record the so-called "biological birth order" independently of the civil status of the mother for the whole of Germany (see Statistisches Bundesamt 2010).

For the new Federal Länder (eastern Germany), the data of the former GDR are available for the period prior to 1989 . These include all births by parity and year of birth of the mother as required for tempo adjustment. After reunification, however, the birth statistics were carried out in accordance with the Federal Population Statistics Act, and thus no official data on births by biological parity is available for Eastern Germany for the period from 1989 to 2008.

This article aims to provide estimates for the TFR* in Western and Eastern Germany from the mid-1950s to the present, and hence to close - at least partly - one of the gaps in international fertility research. In order to separate births by parity as required for tempo adjustment of the TFR, we have used a variety of alternative sources for West Germany as well as for Eastern Germany from 1990 on. These contain estimates for the number or proportion of births by parity and age of the mother 
for different periods, but they are based in some cases on very small population samples with questionable representativity for the overall population. Moreover, in view of the educational and family bias usually found in survey data, it cannot be ruled out that some of these data sources lead to systematic distortions in estimating parity and age at childbirth. Another inaccuracy results from the fact that the data covers different age ranges of the reproductive life span. Although the tempoadjusted fertility rates derived from these data are rather plausible when compared to corresponding estimates for other countries with better data bases, it is important to note that the estimates presented in this paper should not be seen as being on the level of or equivalent to official statistics since they are based on different kinds of data with different degrees of quality.

The methods, and above all the data, on which our estimates of the TFR* for Germany are based are described in detail in the next section. Then we present the results for Western and Eastern Germany both in an intra-German as well as in an international comparison. Finally, we summarise the most important findings and discuss briefly interpretation-related and methodical aspects of the tempo-adjusted total fertility rate. Note that the latter issue as well as a detailed analysis of the fertility trends in Western and Eastern Germany are not the central purpose of this paper. Nonetheless, the advantages and disadvantages of the tempo-adjusted TFR* should be at least briefly summarised for those who have not followed the very detailed discussion on tempo adjustment or those who have not studied it in detail.

\section{Data and methods}

The conventional total fertility rate (TFR), which is published by the German Federal Statistical Office on an annual basis, is calculated from the sum of the age-specific fertility rates $f(x)$, which are calculated by dividing the number of all births of women aged $x, B(x)$, by the number of women aged $x, P(x)$ :

$$
\text { TFR }=\sum_{\alpha}^{\beta} f(x)=\sum_{\alpha}^{\beta} \frac{B(x)}{P(x)} .
$$

Since all indicators in this article refer to periods, we refrain from using an additional index for the calendar year as far as possible for reasons of simplification. The parameters $\alpha$ and $B$ represent the lowest and highest ages of women's reproductive life span, which are usually defined as 15 and 49 years. When totalling the age-specific fertility rates, they all take on the same weight in the resulting TFR, so that - as has already been mentioned in the introduction - the TFR primarily constitutes an age-standardised fertility indicator.

The basic idea behind tempo adjustment of the TFR is not only to standardize for age but also for shifting effects which emerge in a calendar year when the average age of women at childbirth changes during that calendar year (see Bongaarts/Feeney $1998,2006,2010)$. The direction of these changes can differ between parities. Since 
the parities take on different weights in the overall TFR, the tempo adjustment of the TFR according to the method of Bongaarts and Feeney (1998) is performed on a parity-specific basis. This requires separating the TFR in its parity-specific components. The TFR for a parity $i$ is calculated by summing up the corresponding ageand parity-specific fertility rates $f(x)$; which differ from the age-specific fertility rates in equation (1) in that the numerator does not contain all births of women aged $x$, but only births of parity $\mathrm{i}, \mathrm{B}(\mathrm{x})_{\mathrm{i}}$ :

$$
\operatorname{TFR}_{i}=\sum_{\alpha}^{\beta} f(x)_{i}=\sum_{\alpha}^{\beta} \frac{B(x)_{i}}{P(x)} .
$$

Note that these age- and parity-specific fertility rates $f(x)_{i}$ are no probabilities (or any related measure) of the transition of a parity $i$ to the next parity $i+1$. For this purpose, the denominator of the rates should not include all x-year-old women, but only those who actually belong to the female population at risk of giving birth to a child of the i-th birth order (e.g. childless women in the calculation for parity 1). The age- and parity-specific fertility figures from equation (2) rather represent the elements of a purely formal parity-specific decomposition of the TFR as can be demonstrated easily. Subdividing the age-specific numbers of births $B(x)$ in equation (1) into the parities $\mathrm{B}(\mathrm{x})_{1}$ (first births), $\mathrm{B}(\mathrm{x})_{2}$ (second births), $\mathrm{B}(\mathrm{x})_{3}$ (third births) and $B(x)_{4+}$ (fourth and further children), leads to

$$
\mathrm{TFR}=\sum_{\alpha}^{\beta} \frac{\mathrm{B}(\mathrm{x})_{1}+\mathrm{B}(\mathrm{x})_{2}+\mathrm{B}(\mathrm{x})_{3}+\mathrm{B}(\mathrm{x})_{4+}}{\mathrm{P}(\mathrm{x})},
$$

which can be reformulated to

$$
\mathrm{TFR}=\sum_{\alpha}^{\beta} \frac{\mathrm{B}(\mathrm{x})_{1}}{\mathrm{P}(\mathrm{x})}+\sum_{\alpha}^{\beta} \frac{\mathrm{B}(\mathrm{x})_{2}}{\mathrm{P}(\mathrm{x})}+\sum_{\alpha}^{\beta} \frac{\mathrm{B}(\mathrm{x})_{3}}{\mathrm{P}(\mathrm{x})}+\sum_{\alpha}^{\beta} \frac{\mathrm{B}(\mathrm{x})_{4+}}{\mathrm{P}(\mathrm{x})},
$$

so that follows

$$
\operatorname{TFR}=\sum_{\mathrm{i}=1}^{4+} \mathrm{TFR}_{\mathrm{i}}
$$

Tempo adjustment with the method proposed by Bongaarts and Feeney (1998) is done within the parity-specific $T F R_{i}$. Therefore, the $T F R_{i} s$ are divided by one minus the annual change in the average age at childbirth of parity $i, r_{i}$, so that the tempoadjusted parity-specific TFR ${ }_{i}^{*}$ results from 


$$
\mathrm{TFR}_{\mathrm{i}}{ }^{*}=\frac{\mathrm{TFR}_{\mathrm{i}}}{1-\mathrm{r}_{\mathrm{i}}} .
$$

The change in the average age at childbirth of parity i can be estimated by halving the difference between the average parity-specific age at childbirth, $M A B_{i}$, in the following year and the preceding year (see Bongaarts and Feeney 1998). If we denote the analyzed calendar year with $t$, the estimate for $r_{i}(t)$ results from

$$
r_{i}(t)=\frac{M A B_{i}(t+1)-M A B_{i}(t-1)}{2}
$$

We calculated the average parity-specific ages at childbirth $\mathrm{MAB}_{i}$ on an agestandardised basis from the age- and parity-specific fertility rates by

$$
\mathrm{MAB}_{i}=\frac{\sum_{\alpha}^{\beta}(x+0,5) \cdot f(x)_{i}}{\sum_{\alpha}^{\beta} f(x)_{i}}
$$

In accordance with the relations expressed in equations (3), (4) and (5) the overall tempo-adjusted fertility rate TFR* results from the sum of the tempo-adjusted parity-specific $\mathrm{TFR}_{\mathrm{i}}{ }^{*} \mathrm{~s}$ :

$$
\mathrm{TFR}^{*}=\sum_{\mathrm{i}=1}^{4+} \mathrm{TFR}_{\mathrm{i}}{ }^{*}
$$

Tempo adjustment of the total fertility rate requires the number of births to be subdivided by the age of the mothers on a parity-specific basis. The official statistics of the GDR (East Germany) recorded all births by parity and year of birth of the mother, and thus the tempo-adjusted TFR* for East Germany for the period 1955 to 1987 can be directly estimated from these data. For the new Federal Länder since unification in 1990 (Eastern Germany) as well as for the territory of the former Federal Republic of Germany (West respective Western Germany), official data on the biological birth order are only available since 2009. In order to carry out the parityspecific subdivision of the birth numbers necessary for the tempo adjustment of the TFR for West respective Western Germany and Eastern Germany from 1990 onwards, it was necessary to use alternative data sources:

- Birg et al. (1990) provided an estimate of the parity-specific subdivision of births in the Federal Republic of Germany for the years 1958 to 1985 . The estimates were based on the family biographies collected in the context of the research project entitled "Labour market dynamics, family development 
and generative conduct" in 1986, promoted by the DFG, which included 793 women and 783 men of the cohorts born in 1950 and 1955 from Düsseldorf, Hannover, Bochum, Gelsenkirchen, Gronau, Ahaus, Vreden and Leer. For each child of these respondents, the family biographies contain both the actual birth order and the birth order information used by the West German Statistical Office at that time. From the corresponding relative frequencies (obtained for single ages of the mothers by means of linear regression modelling), both the parity-specific births in marriage, and the non-marital births which were recorded in official statistics on a non-parity-specific basis, were transferred into an estimate of the biological parities by single age of the mother. The authors used constant parity-specific subdivisions as obtained from the project sample for both the children born in wedlock and those born out of wedlock for every year from 1958 to 1985.

- Kreyenfeld (2002) combined the official birth numbers for West respective Western Germany from 1985 to 1995 with parity-specific frequencies derived from the Socio-Economic Panel (SOEP) similarly to Birg et al. (1990). However, only the non-marital births of the SOEP samples for West/Western Germany and for foreigners (211 cases in total) were used for the subdivision into the respective birth orders by means of a time-variable multinomial logit model. As a consequence of this modelling procedure, the estimated agespecific parity distributions differ slightly from year to year, in contrast to the estimates of Birg et al. (1990). For marital births, Kreyenfeld (2002) used the official data on birth order of parents who were married to one another.

- For the years 1995 to 1999 (Western Germany) and 1995 to 2000 (Eastern Germany) we could use the data of the perinatal survey compiled and kindly made available by Dr. Manfred Voigt (University of Greifswald). This survey has been carried out since the 1980s directly in West German birth clinics with the aim of improving the quality of perinatal medicine. Participation in the survey, which was conducted by the Bundes/änder themselves until 2000, has been obligatory for all clinics since 1995 (see Goerke/Lack 2000; Kreyenfeld et al. 2010). In contrast to official statistics, the perinatal survey includes the birth order for all births a woman has ever had. Because of the aim and the method of the survey, the perinatal survey exclusively contains births which took place in clinics, what applies to the majority of all births in Germany. Dr. Voigt was able to collect the perinatal survey data for all the Federal Länder with the exception of Baden-Württemberg. Despite the obligatory participation for all hospitals, the dataset for the years 1995 to 1997 contains only approx. $70 \%$ of all 1,656,339 births registered in Germany during these years. The percentages for the single calendar years are about $65 \%$ in 1995, $78 \%$ in 1996 and $66 \%$ in 1997. Nevertheless, the availability of the data for the Federal Länder enabled us to estimate parity-specific proportions of births by the age of the mothers for Eastern and Western Germany separately. For this purpose we used the absolute numbers without addi- 
tional smoothing. Since Berlin is included as one overall unit in the perinatal survey - as in the official statistics from 2000 onwards - we excluded the capital from our analysis.

- Kreyenfeld et al. (2010) also used the data of the perinatal survey, which have been compiled for the whole federal territory since the beginning of the 21st Century by the German National Institute for Quality in Healthcare (Bundesgeschäftsstelle Qualitätssicherung), to estimate parity-specific birth numbers for the years from 2001 to 2008. But also these data are only virtually complete from 2004 onwards. Some hospitals as well as entire Bundes/änder are missing in the years before, such as Hessen, Schleswig-Holstein and the Saarland in 2001. The authors report that 4,978,381 births are recorded (and useable) for the entire period from 2001 to 2008 , corresponding to $89 \%$ of all births registered in Germany in these years. The shares in 2001, 2002 and 2003 are however only between 62 and $85 \%$. Kreyenfeld et al. (2010) provide the parity-specific birth numbers derived from these data separately for Eastern and Western Germany, with all of Berlin being allocated to Eastern Germany. Like the data from the perinatal survey from 1995 to 1999 respective 2000 (see above), the data used by Kreyenfeld et al. (2010) are based solely on births which took place in hospitals. Using data from Germany's official health reporting (Gesundheitsberichterstattung des Bundes) and statistics of the Association for Quality in Out-of-Hospital Births (Gesel/schaft für Qualität in der außerklinischen Geburtshilfe e.V. - QUAG), the authors found that roughly one to two percent of all births took place outside hospitals between 2001 and 2008. Although these figures include primarily higherparity births, taking them into account only leads to negligible changes in the parity-specific subdivision derived from the data of the perinatal survey (see Kreyenfeld et al. 2010).

- In order to close the gap arising from the above mentioned data sources for Western Germany in the year 2000, we also analyzed the parity-specific birth numbers of official statistics for the period 1998 to 2002. As has already been described, these figures only include children born to parents who are currently married to one another including their joint pre-marital children. The quality of the TFR* estimated on the basis of these data mainly depends on the extent of deviations between the average age at childbirth of the women by the biological birth order and by the birth order in the current marriage. Analysing the new official statistics for 2009 one asserts that this extent mainly depends on the proportion of non-marital births (Statistisches Bundesamt 2010). The difference between the age of the mother at the first birth in the current marriage and the age of the mother at the first birth in her life was 0.9 years in Western Germany in 2009 with the proportion of extramarital first births being $36 \%$. The proportion of extra-marital births was smaller among second and further births, namely between $17 \%$ and $19 \%$, and the corresponding age difference was only 0.3 years. The influence of 
re-marriage was weak: $93 \%$ of first births in the current marriage in 2009 were also the first births in the life of the mother. The concordance between biological and marital birth order was even larger in second and further births. Thus, since the proportion of births of unmarried women among all live births in Western Germany in the years 1998 to 2002 was between $16 \%$ and $21 \%$ (Statistisches Bundesamt 2008, Tab. 1.1.1 to 1.1.3), the information on the marital birth order forms a relatively sound basis for estimating the $\mathrm{TFR}^{*}$. The situation for Eastern Germany is different what prohibits using the information from official statistics on the marital birth order: The proportion of extra-marital births is much larger than in Western Germany. The proportion of extra-marital births among first births was $74 \%$ in 2009, and among second and further births it was still far above $40 \%$. The difference between the age at the first birth in the life of the woman and the age at the first birth in the current marriage was 2.3 years. Between second and further births, the age difference was 0.9 and 0.8 years, respectively. Furthermore, $20 \%$ of the women had already given birth before the first child in the current marriage was born. The proportion of extra-marital births in the new Federal Länder in the period between 1998 and 2002 was more than twice as high as in the West, and it increased more rapidly: from $47 \%$ in 1998 to $55 \%$ in 2002 .

Table 1 summarizes the data sources used. As far as we know, these contain the only data existing for the German population which provide the subdivision of births into first births (parity 1), second births (parity 2), third births (parity 3 ) and higher-order births (parity 4+) for the years 1955 to 2008. Since the case numbers in the data sources used differ from the total number of births registered in Western and Eastern Germany, the relative parity-specific subdivision of births, calculated from the data sources, was applied to the total number of births in Western and Eastern Germany as published by the statistical office. In formal terms, the age- and parity-specific numbers of births $B(x)_{i}$ were estimated as follows:

with $B(x)$ denoting the official overall number of births of $x$-year-old women, and

$$
B(x)_{i}=B(x) \cdot \frac{B^{\prime}(x)_{i}}{B^{\prime}(x)}
$$

$B^{\prime}(x)_{i}$ and $B^{\prime}(x)$, respectively, denoting the number of births of parity $i$ of $x$-year-old women as well as the corresponding total number of births included in the respective data source. From these age- and parity-specific birth numbers and from the numbers of living women aged 15 to 49 published by the statistical office, it was possible to derive age- and parity-specific fertility rates for single ages of the mothers which finally enabled us to estimate the parity-specific $T F R_{i}$ from equation (2) as well as the parity-specific age at childbirth $M A B_{i}$ from equation (8). The tempo-adjusted total fertility rates TFR* were finally calculated as shown in equation (9). For parities 1, 2 and 3 we used the tempo-adjusted $\mathrm{TFR}_{1}{ }^{*}, \mathrm{TFR}_{2}{ }^{*}$ and $\mathrm{TFR}_{3}{ }^{*}$ (calculated 
Tab. 1: Data sources used to estimate age- and parity-specific fertility rates

(a) Western Germany (former Federal Republic of Germany/old Federal Länder)

\begin{tabular}{|c|c|c|}
\hline Data source & Period used & Basis of the parity-specific subdivision of births \\
\hline Birg et al. (1990) & $1958-1985$ & $\begin{array}{l}\text { Marital and extra-marital births from the sample } \\
\text { of the project entitled "Labour market dynamics, } \\
\text { family development and generative conduct", } \\
\text { ages } 15-49\end{array}$ \\
\hline Kreyenfeld (2002) & $1985-1995$ & $\begin{array}{l}\text { Extra-marital births from the sample of the SOEP, } \\
\text { marital births from official statistics, ages } 15-45\end{array}$ \\
\hline Perinatal data & $1995-1999$ & $\begin{array}{l}\text { Births recorded in the perinatal survey in } \\
\text { Western Germany without the Baden- } \\
\text { Württemberg and West Berlin, ages 15-49 }\end{array}$ \\
\hline Official birth statistics & $1998-2002$ & $\begin{array}{l}\text { Births from the current marriage (without West } \\
\text { Berlin from } 2001 \text { on), ages } 15-49\end{array}$ \\
\hline Kreyenfeld et al. (2010) & $2001-2008$ & $\begin{array}{l}\text { Births recorded in the perinatal survey in } \\
\text { Western Germany without West Berlin, ages } \\
15-44\end{array}$ \\
\hline Official birth statistics & 2009 & All births (without West Berlin), ages 15-49 \\
\hline
\end{tabular}

(b) Eastern Germany (former GDR/new Federal Länder)

\begin{tabular}{lcl}
\hline Data source & Period used & Basis of the parity-specific subdivision of births \\
\hline $\begin{array}{l}\text { Official birth statistics } \\
\text { of the GDR }\end{array}$ & $1954-1988$ & All births, ages 15-45 \\
$\begin{array}{l}\text { Perinatal data } \\
\text { Kreyenfeld et al. (2010) }\end{array}$ & $2001-2008$ & $\begin{array}{l}\text { Births recorded in the perinatal survey in Eastern } \\
\text { Germany without East Berlin, ages 15-49 } \\
\text { Germany including West Berlin, ages 15-44 }\end{array}$ \\
$\begin{array}{l}\text { Official birth statistics } \\
\text { All births (without East Berlin), ages 15-49 }\end{array}$ \\
\hline
\end{tabular}

with equation 6), whereas for parity $4+$ we used the conventional TFR $4+$ as recommended by Sobotka (2004a) in order to reduce random fluctuations.

\section{Results}

In a first step, we subdivided the total number of births by the age of the mother for Western and Eastern Germany published by the Statistical Office of Germany into the parities on the basis of the parity distributions reconstructed from the various data sources. From these parity-specific birth numbers, we decomposed the con- 
ventional total fertility rate TFR - as described in the previous section - into parities 1, 2, 3 and 4+. The corresponding estimates for TFR $, \mathrm{TFR}_{2}, \mathrm{TFR}_{3}$ and $\mathrm{TFR}_{4+}$ for each calendar year can be found in Annex 1.

Figure 1 shows the proportions of the parity-specific TFR from 1958 to 2008 calculated from these data. Although the time trends of the parity-specific proportions of the TFR reveal interesting differences between Western and Eastern Germany, both parts of the country resemble each other in the fact that total fertility is mainly determined by parities 1 and 2 . All in all, first and second born children account for $70 \%$ (from the end of the 1950 s until the 1960 s) to $80-85 \%$ (since the 1970 s in Eastern Germany and since the 1980s in Western Germany) of the total number of live births in the analyzed period. The proportions of parity 3 remain largely constant in both Western and Eastern Germany, whilst births of fourth and higher order have clearly become less significant since the 1970s in both parts of Germany and are of only minor significance for total fertility. With regard to the tempo effect component in the conventional TFR it is therefore of primary relevance how the average age at childbirth of mothers of first and second children has changed in the analyzed calendar years.

Fig. 1: Proportions of parity-specific TFRis in the conventional total fertility rate TFR in Western and Eastern Germany, 1958-2008

(a) Western Germany

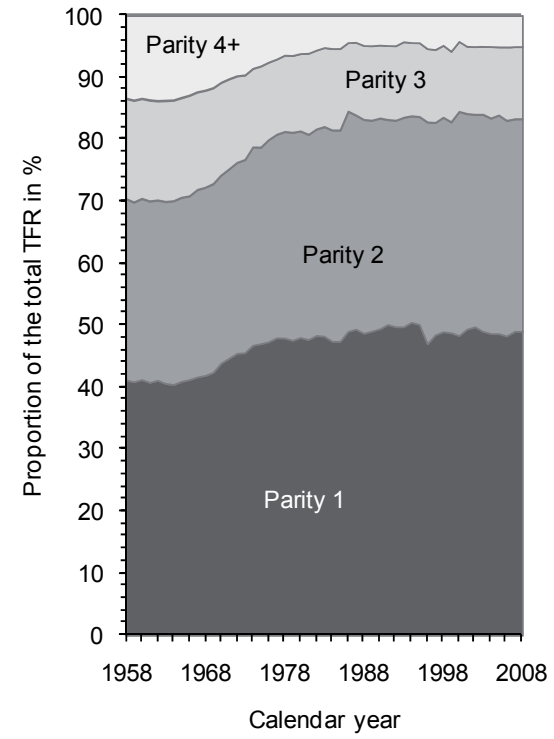

(b) Eastern Germany

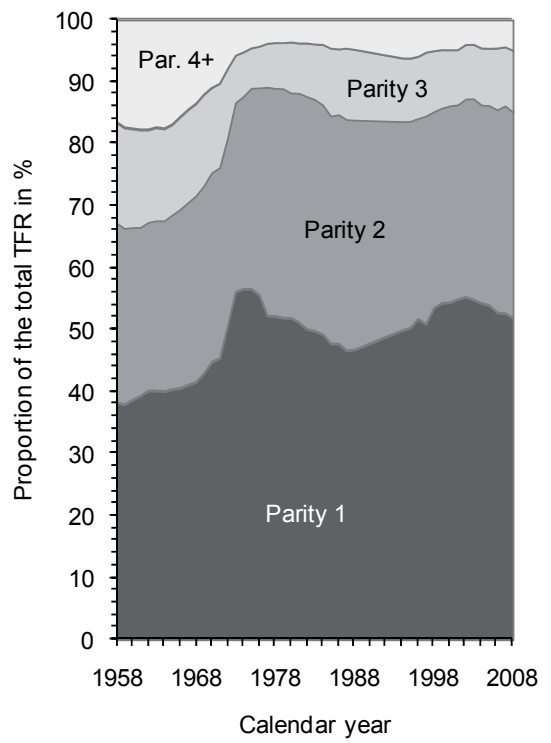

Notes: Data basis of the estimates for Western Germany for the years 1958-1985 Birg et al. (1990), 1986-1995 Kreyenfeld (2002), 1996-1999 perinatal survey, 2000 official statistics (marital births), 2001-2008 Kreyenfeld et al. (2010); data basis of the estimates for Eastern Germany for the years 1954-1988 official statistics of the GDR, 1995-2000 perinatal survey, 2001-2008 Kreyenfeld et al. (2010); the missing calendar years 1989-1994 for Eastern Germany were estimated by means of linear interpolation of the values for 1988 and 1995; the parity-specific TFR ${ }_{\mathfrak{j}}$ for single calendar years can be found in Annex 1. 
Figures $2 \mathrm{a}$ to $2 \mathrm{~d}$ present the annual changes in the average parity-specific age at childbirth $r_{i}$ for the same observation period estimated from the age- and parityspecific numbers of births. The values for parity 1 in Western Germany (black dots in Fig. 2a) are to be found exclusively in the negative range until the beginning of the 1970s. This means that the average age of women giving birth for the first time is continuously decreased during these years. The situation is similar for the average age at childbirth of parities 2 (shown in Fig. 2a by white triangles) and 3 (star signature in Fig. 2c). Consequently, one can presume that tempo effects increased the conventional TFR in the years of the baby boom. The changes in the average age of the mothers of children of fourth and higher order (grey squares in Fig. 2c) show a trend in contrast to parities 1 and 2 between the mid-1960s and the beginning of the 1970 s. Because of the minor significance of parity $4+$ for total fertility, this can only result in a slight reduction of the tempo effects caused by parities 1, 2 and 3 . From the 1970s to the end of the 1990s, all parities show an almost permanent annual increase in the average age at childbirth in Western Germany, albeit with varying intensities. Above all in parity 1 , the annual changes are more than 0.1 years in most calendar years, with the maximum value of 0.26 being reached in 1983 . Only in the second half of the 1980s the values for $r_{1}$ are around zero. Since the early 1990s, there is a rise in the annual increase again, with an overall upward trend until the last year of observation. The changes in the other parities are very similar over the entire period. In the last years of the observation period, the annual change in the average age at childbirth among parities 1 to 3 is between 0.15 and 0.20 years, so that the TFR in Western Germany was influenced most by tempo effects in the 1970s and early 1980 s as well as since the early 1990 s.

In Eastern Germany, the values for $r_{i}$ of all parities fluctuate around zero from the mid-1960s until the end of the 1980s (see Figs. $2 b$ and $2 d$ ). The few exceptions relate to parities 2, 3 and 4+ for a short time around 1970 and to parity 4+ at the end of the 1970 s and at the beginning of the 1980s. All in all, the conventional TFR in Eastern Germany should be more or less unaffected by tempo effects in this period. Since unification, the trends have changed considerably. Unfortunately, for the years between 1987 and 1996 the change in the average age at childbirth cannot be estimated. However, the $r_{i}$ values derived for the years from 1996 to 2000 are - above all for parities 1 and 2 - very high and much higher than in Western Germany. The dashed interpolated lines in Figures 2b and 2d between 1987 and 1996 are included to provide an impression of the massive changes which occurred in the ages at childbirth among Eastern German mothers during the 1990s. These lines cannot be used to estimate the $r_{i}$ values for the single years of this period, which could indeed have been rather above the level of 1996 particularly in the first half of the 1990s. However, they indicate that the extremely low TFR of Eastern Germany in this period is caused to a considerable degree by tempo effects. From the beginning of the $20^{\text {th }}$ century on the annual change in the average age at childbirth returns to a level of around 0.2 years among parities 1 and 2, and is hence similar to the West German level. The fluctuations are larger in parities 3 and $4+$ with many of the single values being around zero. However, as can be seen in Figure 1b, the changes in the ages at 
Fig. 2: Annual changes in the average parity-specific age at childbirth $r_{i}$ in Western and Eastern Germany, 1958-2008

(a) parities 1 and 2, Western Germany

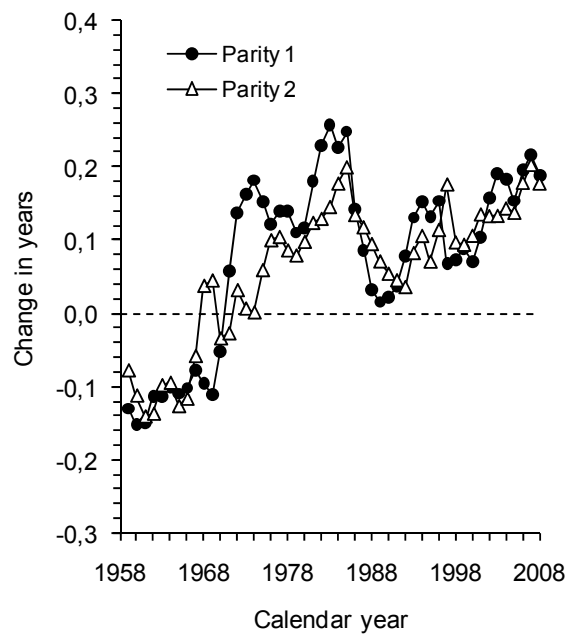

(c) parities 3 and 4+, Western Germany

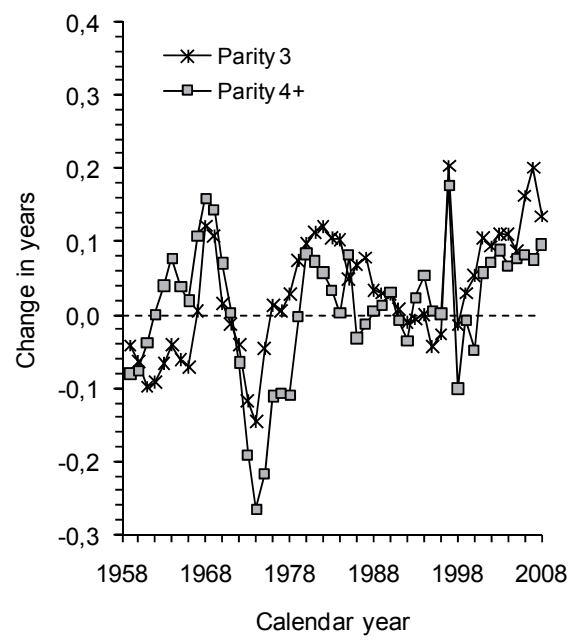

(b) parities 1 and 2, Eastern Germany

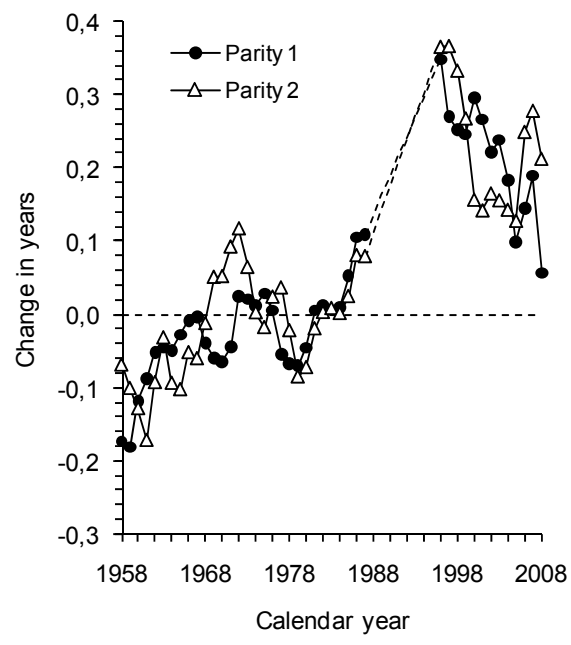

(d) parities 3 and 4+, Eastern Germany

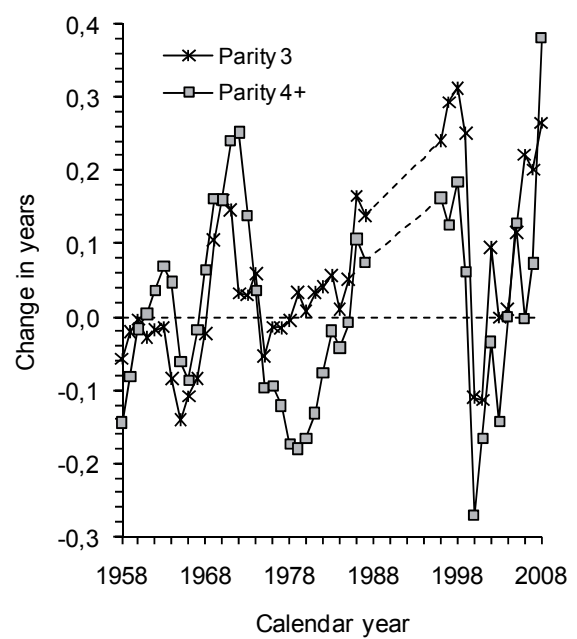

Notes: Data basis of the estimates for Western Germany for the years 1959-1984 Birg et al. (1990), 1985 combination Birg et al. (1990)/Kreyenfeld (2002), 1986-1994 Kreyenfeld (2002), 1995 combination Kreyenfeld (2002)/perinatal survey, 1996-1998 perinatal survey, 1999-2001 official statistics (marital births), 2002-2007 Kreyenfeld et al. (2010), 2008 combination Kreyenfeld et al. (2010)/official statistics (all births); data basis of the estimates for Eastern Germany for the years 1958-1987 official statistics of the GDR, 1996-1999 perinatal survey, 2000-2001 combination perinatal survey/Kreyenfeld et al. (2010), 2002-2007 Kreyenfeld et al. (2010), 2008 combination Kreyenfeld et al. (2010)/official statistics (all births). 
childbirth of the mothers of third and further children have only a minor influence on the magnitude of the tempo effects.

The estimated annual changes in the parity-specific age at childbirth can be used to adjust the TFR $\mathrm{i}$ for tempo effects according to the method proposed by Bongaarts and Feeney (1998), and the resulting TFRi*s can then be cumulated to the tempo-adjusted total fertility rate TFR* (the values for the TFR ${ }^{*}$ and the total TFR* can be found for the single calendar years in Annex 2). Figure 3 shows the corresponding estimates for Western Germany in comparison to the conventional TFR (thin line). All in all, the estimates for the tempo-adjusted TFR* derived from the various data sources (designated in Fig. 3 by different symbols) show a coherent overall trend.

Since tempo adjustment with the method of Bongaarts and Feeney (1998) can generally lead to distinct annual fluctuations (and here additionally the combination of different data sources), more robust results are obtained when averaging the tempo-adjusted TFR* for three calendar years (see Goldstein et al. 2009). The resulting estimates for the TFR* ${ }^{*}$ of Western Germany can be found in Table 2a. The thick black line in Fig. 3 represents the corresponding trend of the TFR* which reflects the expectations that have already been outlined in connection with the trends in the annual changes in parity-specific ages at childbirth. The TFR* is slightly below the conventional TFR from the late 1950s to the mid-1960s because the age at childbirth was falling at that time. This shows that the increase in the TFR at the beginning of the baby boom in the 1950s was not only caused by the actual increase in fertility but also to a slight degree by tempo effects. Similar results were shown for instance for the USA (Bongaarts/Feeney 1998). At the end of the 1960s and at the beginning of the 1970s, practically no differences can be found between the TFR and the TFR*.

Since the early 1970s, the TFR* in Western Germany has been higher than the conventional TFR. Whilst the TFR stagnated between 1.3 and 1.4 after the fertility decline between the second half of the 1960s and the mid-1970s, the TFR* declined less in the 1970s, and at the beginning of the 1980s the TFR* increased slightly to about 1.7. The following years show a subsequent decrease in the TFR* that persisted until 1990. Since then, the tempo-adjusted total fertility rate shows a more or less continuous increase, reaching almost 1.7 in the last year of the observation period (2008). All in all, although the TFR* is far from the replacement level of 2.1 children per woman (upper dashed line in Fig. 3), it lies - in contrast to the conventional TFR - clearly above the level of "lowest-low fertility", which Kohler et al. (2002) defined as 1.3 children per woman (lower dashed line in Fig. 3).

The differences between the conventional TFR and the tempo-adjusted TFR* also correspond to the expectations for Eastern Germany outlined above on the basis of the estimated annual changes in the average parity-specific age at childbirth. In Figure 4 the corresponding estimates are, again displayed for the single years and the trend in the three-year average of the TFR* (the respective values can be found in Tab. 2b, as well as in Annex 2). It can be seen that tempo effects also led to a slight increase in the total fertility rate during the 1950s in Eastern Germany which is indicated by the somewhat lower values of the TFR* in comparison to the TFR. 
Fig. 3: Estimates of the tempo-adjusted total fertility rate TFR* in Western Germany from various data sources, 1950-2010

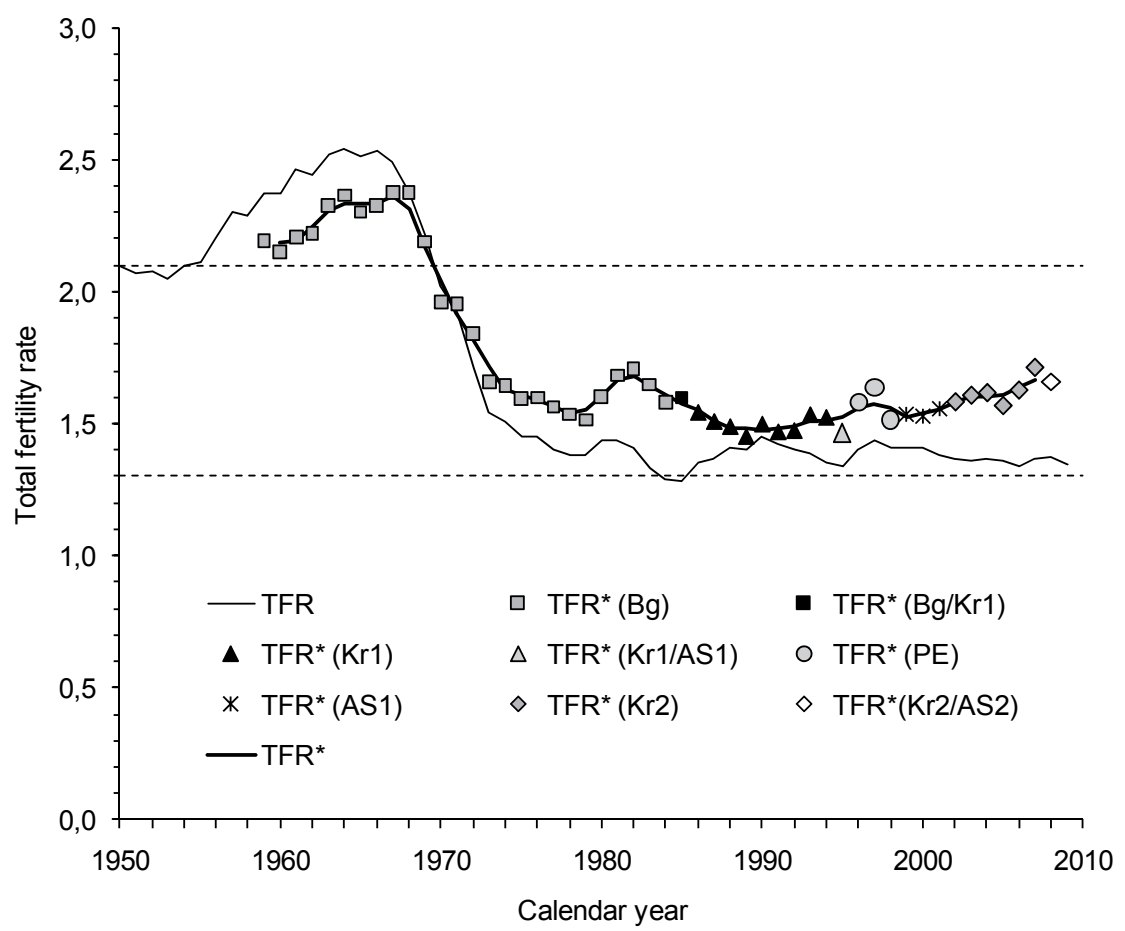

Notes: The abbreviations in brackets refer to the data basis for the estimate of the TFR*, $\mathrm{Bg}=$ Birg et al. (1990), $\mathrm{Kr} 1=$ Kreyenfeld (2002), $\mathrm{Kr} 2=$ Kreyenfeld et al. (2010), $\mathrm{PE}=$ perinatal survey, AS1 = official statistics (marital births), $\mathrm{Bg} / \mathrm{Kr} 1=$ combination Birg et al. (1990)/Kreyenfeld (2002), Kr1/PE = combination Kreyenfeld (2002)/perinatal survey, Kr2/ AS2 = combination Kreyenfeld et al. (2010)/official statistics (all births); the trend line of the TFR* is calculated from a three-year moving average (values for the mid-calendar years can be found in Tab. 2); the parity-specific TFRi ${ }^{*}$ s for the single calendar years can be found in Annex 2.

In the subsequent years until the mid-1980s, the annual changes in the mothers' average age at childbirth were too small to lead to significant tempo effects. Consequently, there are virtually no differences between the TFR and the TFR* in this period. This changes in the last years prior to reunification during which the TFR* in Eastern Germany rises in contrast to the decreasing TFR because of the increasing age at childbirth, similar to what can be observed for Western Germany at the end of the 1970s.

Although we have only few estimates for the TFR* in the 1990s because of the available data sources, these estimates illustrate to what degree the conventional TFR (and the actual birth numbers) were affected by changes in the mean age at childbirth in Eastern Germany. Whereas the conventional TFR was only 1.04 in 1997, the estimated tempo-adjusted TFR* is 1.47 . Equally to what has been done in Fig- 
Tab. 2: Estimates of the tempo-adjusted total fertility rate TFR* in Western and Eastern Germany, 1950-2010 (three-years averages)

\begin{tabular}{|c|c|c|c|c|c|c|c|c|c|c|c|}
\hline \multicolumn{12}{|c|}{ (a) Western Germany } \\
\hline \multicolumn{2}{|c|}{$1950-1959$} & \multicolumn{2}{|c|}{$1960-1969$} & \multicolumn{2}{|c|}{ 1970-1979 } & \multicolumn{2}{|c|}{ 1980-1989 } & \multicolumn{2}{|c|}{ 1990-1999 } & \multicolumn{2}{|c|}{$2000-2009$} \\
\hline Year & $\mathrm{TFR}^{*}$ & Year & $\mathrm{TFR}^{*}$ & Year & $\mathrm{TFR}^{*}$ & Year & $\mathrm{TFR}^{*}$ & Year & $\mathrm{TFR}^{*}$ & Year & $\mathrm{TFR}^{*}$ \\
\hline 1950 & -- & 1960 & 2.18 & 1970 & 2.03 & 1980 & 1.60 & 1990 & 1.47 & 2000 & 1.54 \\
\hline 1951 & -- & 1961 & 2.19 & 1971 & 1.92 & 1981 & 1.66 & 1991 & 1.48 & 2001 & 1.56 \\
\hline 1952 & -- & 1962 & 2.25 & 1972 & 1.82 & 1982 & 1.68 & 1992 & 1.49 & 2002 & 1.58 \\
\hline 1953 & -- & 1963 & 2.30 & 1973 & 1.71 & 1983 & 1.65 & 1993 & 1.51 & 2003 & 1.60 \\
\hline 1954 & -- & 1964 & 2.33 & 1974 & 1.63 & 1984 & 1.61 & 1994 & 1.51 & 2004 & 1.60 \\
\hline 1955 & -- & 1965 & 2.33 & 1975 & 1.61 & 1985 & 1.57 & 1995 & 1.52 & 2005 & 1.61 \\
\hline 1956 & -- & 1966 & 2.34 & 1976 & 1.59 & 1986 & 1.55 & 1996 & 1.56 & 2006 & 1.64 \\
\hline 1957 & -- & 1967 & 2.36 & 1977 & 1.57 & 1987 & 1.51 & 1997 & 1.58 & 2007 & 1.67 \\
\hline 1958 & -- & 1968 & 2.31 & 1978 & 1.54 & 1988 & 1.48 & 1998 & 1.56 & 2008 & -- \\
\hline 1959 & -- & 1969 & 2.17 & 1979 & 1.55 & 1989 & 1.48 & 1999 & 1.53 & 2009 & -- \\
\hline \multicolumn{12}{|c|}{ (b) Eastern Germany } \\
\hline \multicolumn{2}{|c|}{$1950-1959$} & \multicolumn{2}{|c|}{$1960-1969$} & \multicolumn{2}{|c|}{$1970-1979$} & \multicolumn{2}{|c|}{ 1980-1989 } & \multicolumn{2}{|c|}{ 1990-1999 } & \multicolumn{2}{|c|}{$2000-2009$} \\
\hline Year & $\mathrm{TFR}^{*}$ & Year & $\mathrm{TFR}^{*}$ & Year & $\mathrm{TFR}^{*}$ & Year & $\mathrm{TFR}^{*}$ & Year & $\mathrm{TFR}^{*}$ & Year & $\mathrm{TFR}^{*}$ \\
\hline 1950 & -- & 1960 & 2.18 & 1970 & 2.23 & 1980 & 1.83 & 1990 & -- & 2000 & 1.53 \\
\hline 1951 & -- & 1961 & 2.24 & 1971 & 2.11 & 1981 & 1.86 & 1991 & -- & 2001 & 1.53 \\
\hline 1952 & -- & 1962 & 2.31 & 1972 & 1.91 & 1982 & 1.85 & 1992 & -- & 2002 & 1.53 \\
\hline 1953 & -- & 1963 & 2.35 & 1973 & 1.69 & 1983 & 1.81 & 1993 & -- & 2003 & 1.54 \\
\hline 1954 & -- & 1964 & 2.37 & 1974 & 1.58 & 1984 & 1.79 & 1994 & -- & 2004 & 1.52 \\
\hline 1955 & -- & 1965 & 2.35 & 1975 & 1.59 & 1985 & 1.81 & 1995 & -- & 2005 & 1.53 \\
\hline 1956 & 2.12 & 1966 & 2.32 & 1976 & 1.68 & 1986 & 1.87 & 1996 & -- & 2006 & 1.60 \\
\hline 1957 & 2.07 & 1967 & 2.29 & 1977 & 1.77 & 1987 & -- & 1997 & 1.47 & 2007 & 1.65 \\
\hline 1958 & 2.09 & 1968 & 2.26 & 1978 & 1.81 & 1988 & -- & 1998 & 1.50 & 2008 & -- \\
\hline 1959 & 2.12 & 1969 & 2.24 & 1979 & 1.82 & 1989 & -- & 1999 & 1.52 & 2009 & -- \\
\hline
\end{tabular}

Notes: -- no estimates available; values for the TFR* calculated from the three-year moving average of the estimates for the single calendar years (see Annex 2).

ure $2 b$, the dashed sections of the line for the tempo-adjusted TFR* in Figure 4 are only included to give an impression of the fertility conditions prevailing in the first half of the 1990s. In fact, the TFR* could have also been below this line during these years as indicated by the estimate for the single year 1996. From 1997 to 2005, the tempo adjusted $\mathrm{TFR}^{*}$ ranged relatively constant around 1.5 . Whether the increase in the $T F R^{*}$ in the last years of the observation period as indicated by the estimates from 2006 onwards reflects an actual trend can only be said once the data for the next years become available. 
Fig. 4: Estimates of the tempo-adjusted total fertility rate TFR* in Eastern Germany from various data sources, 1950-2010

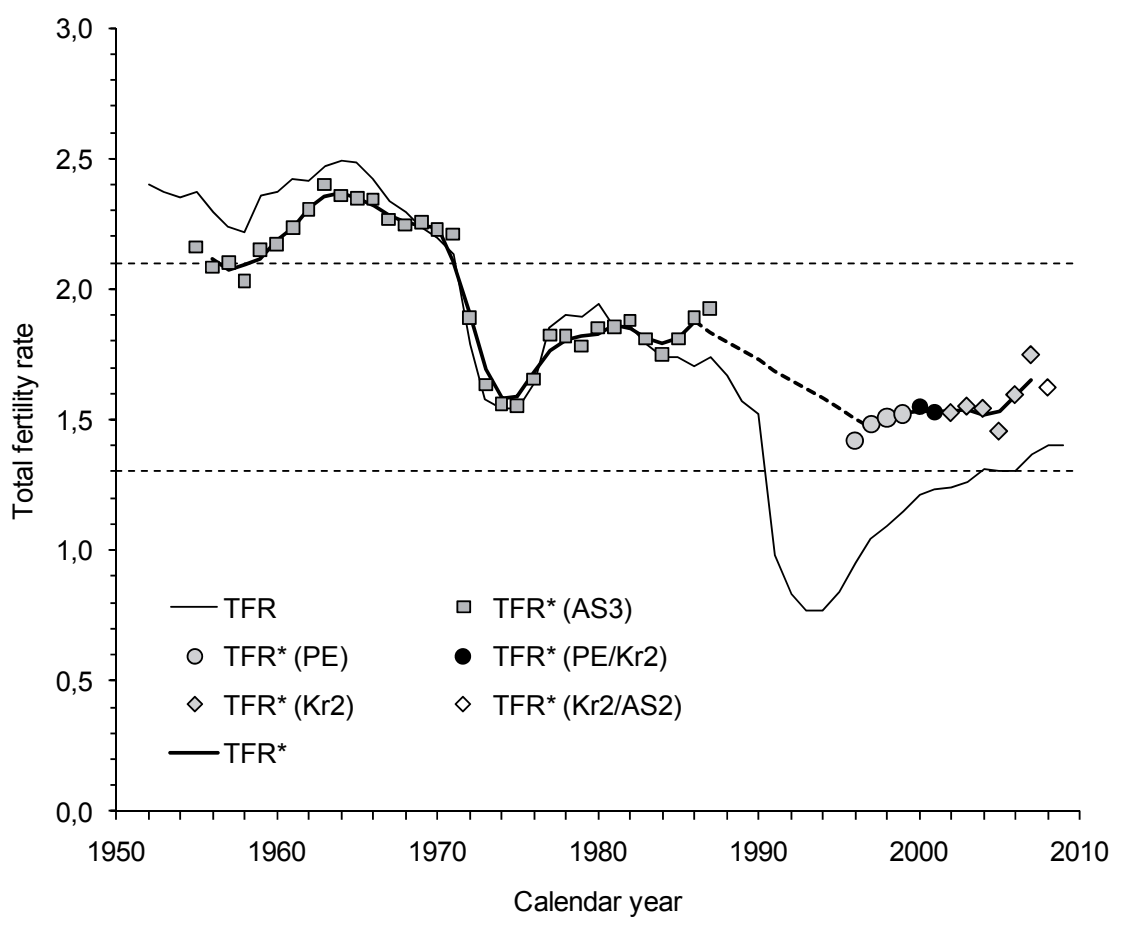

Notes: The abbreviations in brackets refer to the data basis for the estimate of the TFR*, AS3 = official statistics (GDR), PE = perinatal survey, $\mathrm{Kr} 2=$ Kreyenfeld et al. (2010), PE/Kr2 $=$ combination perinatal survey/Kreyenfeld et al. (2010), Kr2/AS2 = combination Kreyenfeld et al. (2010)/official statistics (all births); the trend line of the TFR* is calculated from the three-year moving average (values for the mid calendar years can be found in Tab. 2); for the calendar years 1987-1996, the trend for the TFR* in Eastern Germany (years without estimate) was completed by linear interpolation of the values for 1986 and 1997 (dashed line); the parity-specific TFR ${ }_{i}^{*}$ s for the single calendar years can be found in Annex 2 .

A direct East-West comparison of fertility trends in Germany is presented in Figure 5 according to the conventional TFR and the tempo-adjusted TFR* ${ }^{*}$. The trends in the conventional TFR can be found in Figure $5 \mathrm{a}$ and the trends in the tempoadjusted TFR* can be found in Figure $5 \mathrm{~b}$. Interestingly, both variants of calculation show the same phases in which the total fertility rate is higher in Eastern or Western Germany. However, the differences in the tempo-adjusted TFR* in the two parts of Germany are smaller in each phase (and since the second half of the 1990s almost negligible). (Note once more that the dashed sections in the line of the TFR* for Eastern Germany are no real estimates, but represent the interpolated connection between the estimates for 1986 and 1997.) Besides this, the graphical West-East comparison of the total fertility rate by means of the two calculation variants provides one more important result: fertility had virtually disappeared at the end of the 
Fig. 5: Total fertility rate in Western and Eastern Germany according to the conventional TFR and the tempo-adjusted TFR*, 1950-2010

(a) conventional TFR

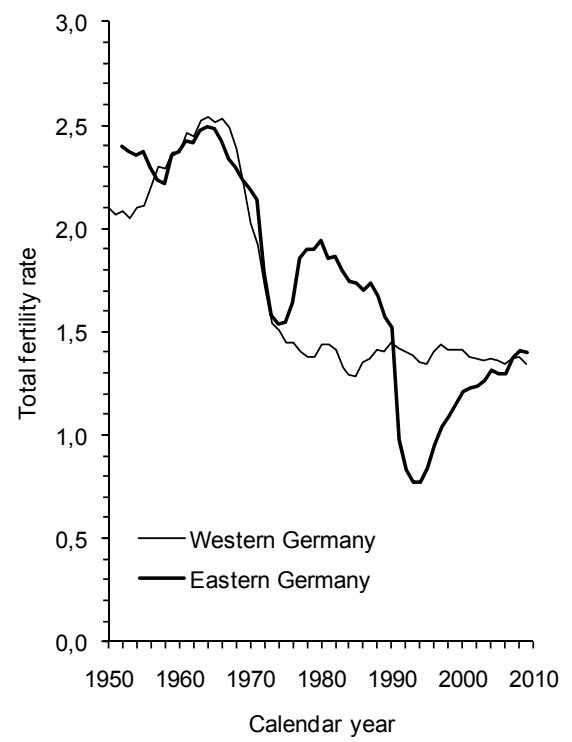

(b) tempo-adjusted TFR*

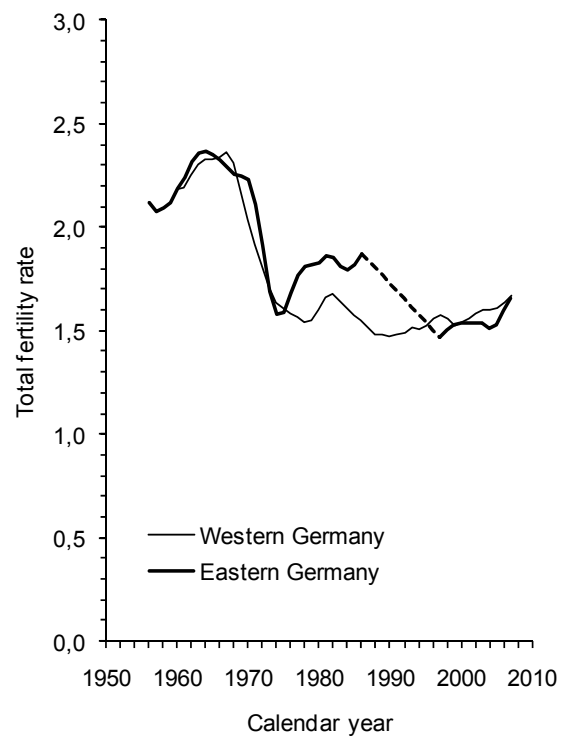

Notes: Values for the tempo-adjusted TFR* from the three-year moving average of the estimates for the single calendar years (see Tab. 2); for the calendar years 1987-1996, the trend for the TFR* in Eastern Germany (years without estimate) was completed by linear interpolation of the values for 1986 and 1997 (dashed line).

observation period. This holds for both versions of the total fertility rate, namely the conventional TFR and the tempo-adjusted TFR*.

Finally, Figure 6 (Western Germany) and Figure 7 (Eastern Germany) show the trends in the TFR as well as in the TFR* in comparison to three other western and eastern European populations for which the corresponding values could be calculated from the Human Fertility Database (HFD) (the TFR* for these populations was calculated analogously to our estimates for Western and Eastern Germany, i.e. using the tempo-adjusted TFR ${ }_{i}^{*}$ for parities 1,2 and 3 and the conventional TFR $R_{i}$ for the higher parities, presented by means of three-year moving averages). Equally to what has been done in Figure 5, the graphs on the left-hand side show the conventional TFR and the graphs on the right-hand side show the tempo-adjusted TFR*. The figures are intended to enable us to evaluate the degree to which our estimates of the TFR* for Western and Eastern Germany derived from data sources of different quality can be regarded as plausible. It can be assumed that populations with comparable demographic conditions and trends also show similar trends in tempo effects. This, however, is a more intuitive concept rather than real empirical evidence, More so if one takes into consideration that despite the common features 
Fig. 6: Total fertility rate in Western Germany in comparison to other Western European populations according to the conventional TFR and the tempo-adjusted TFR*, 1950-2010
(a) conventional TFR
(b) tempo-adjusted TFR*
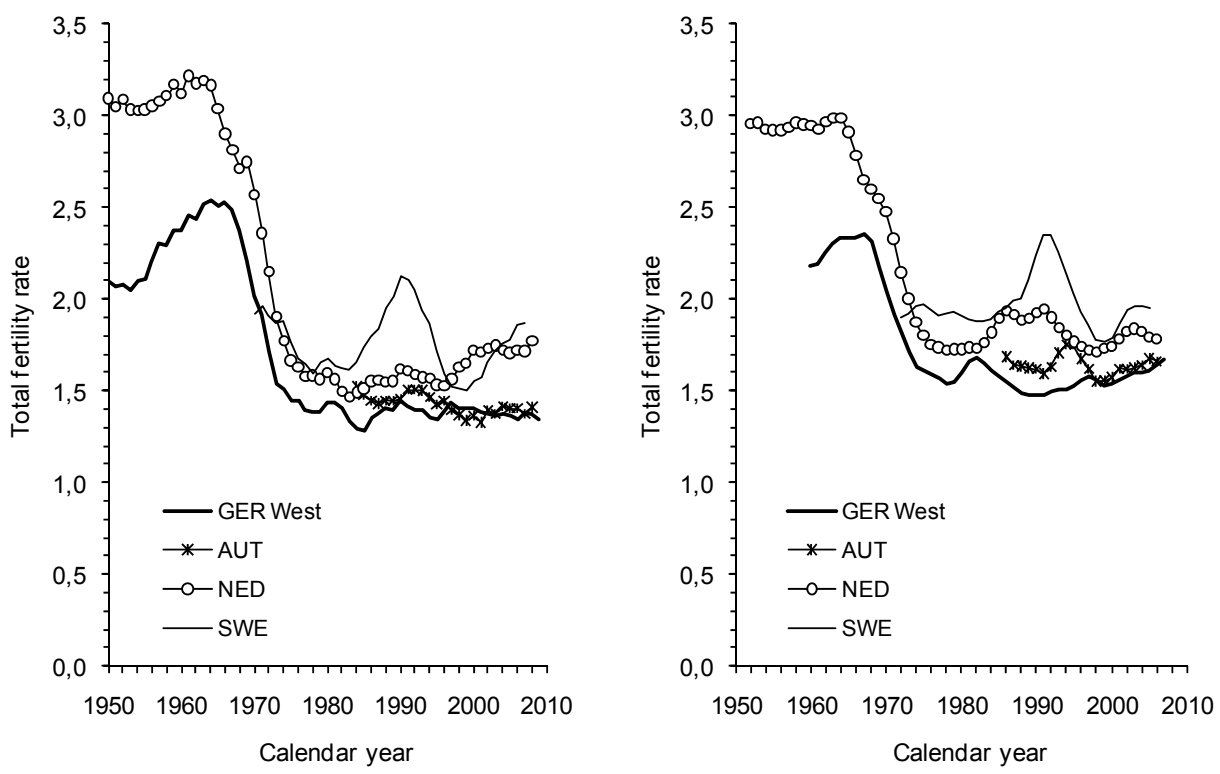

Notes: Values for the tempo-adjusted TFR* for Western Germany (GER West) reflect the three-year moving average of the estimates for the single calendar years (see Tab. 2); values for Austria (AUT), the Netherlands (NED) and Sweden (SWE) calculated with data from the Human Fertility Database (HFD), three-year moving averages.

there are also historic and socio-structural differences between the two populations under consideration.

The trends of the conventional TFR in Western Germany, Austria, the Netherlands and Sweden shown in Figure 6a reflect the already known fact that the West German fertility level is located at the low end of the range in other western European populations. Austria is comparable to Western Germany with regard to the level and trend of the TFR since the 1980s (the HFD provides data for Austria only since this time). In Sweden and in the Netherlands, the TFR has increased in the last ten years, in contrast to the stagnation observed in Western Germany and Austria, where it ranges around the level of 1.8 to 1.9 in most recent years. Figure $6 \mathrm{~b}$ reveals that the estimates for the TFR* of Western Germany are also close to the corresponding values of Austria, for which age- and parity-specific birth numbers of the total population are published directly by the national statistical office (Statistik Austria). This finding holds for the mid-1990s onwards. In the years before, at around 1990, the Austrian TFR* shows a strong fluctuation which is not visible in the conventional TFR. All in all, the estimates for the TFR* of Western Germany fit well and plausible into the picture of the Western European populations. Only in the 1980s and early 
1990s the estimates for the TFR* seem somewhat too low. An interesting result is that in the most recent years the differences in the total fertility rate between Western Germany and Austria, on the one hand, and Sweden and the Netherlands, on the other, are much smaller when the TFR is tempo adjusted.

Figure 7 also includes one population which seems suitable for comparison with Eastern Germany in order to judge the plausibility of our tempo-adjusted estimates. Roughly since 1980, Slovenia shows a similar trend in the conventional TFR compared to that of Eastern Germany. In the 1990s, however, both differ when no fertility changes comparable to those in Eastern Germany occurred in Slovenia (see Fig. 7a). The two other populations, from the Czech and Slovak Republics, exhibit a much higher TFR until the mid-1990s, but show similar changes in the fertility level as the East German population in the first half of the 1990s (albeit without recovery after the baby bust). The comparison of the estimates for the East German tempoadjusted TFR* with the corresponding figures for the three other populations in Figure $7 \mathrm{~b}$ also shows that the estimates for Eastern Germany seem highly plausible.

Fig. 7: Total fertility rate in Eastern Germany in comparison to other eastern European populations according to the conventional TFR and the tempo-adjusted TFR ${ }^{*}$, 1950-2010

(a) conventional TFR

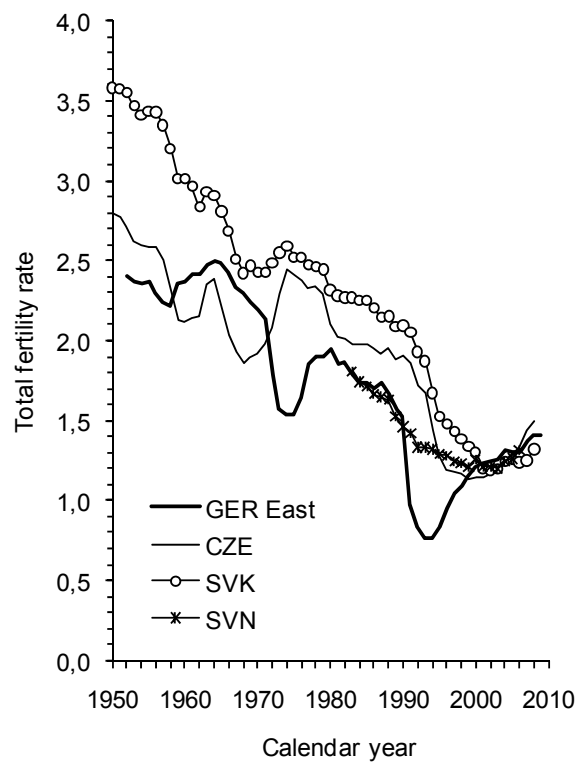

(b) tempo-adjusted TFR*

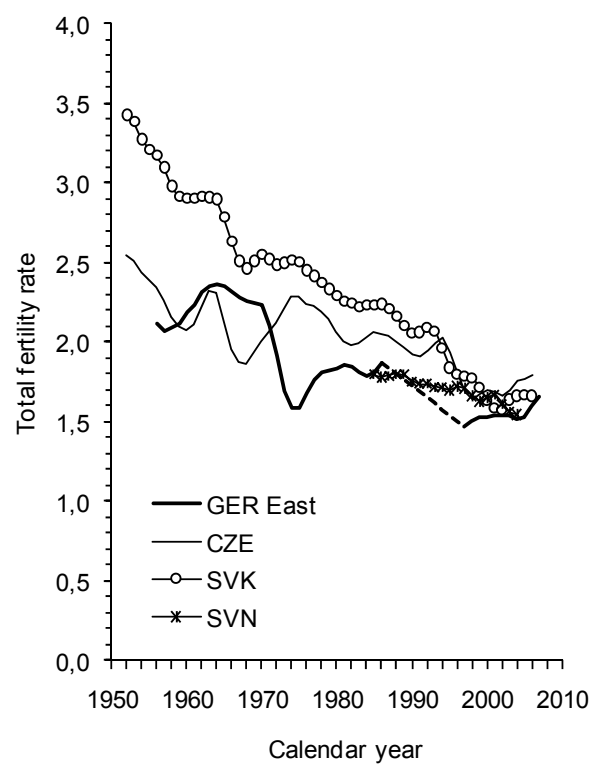

Notes: Values for the tempo-adjusted TFR* for Eastern Germany (GER East) reflect the three-year moving average of the estimates for the single calendar years (see Tab. 2); the trend for the TFR* in Eastern Germany for the calendar years 1987-1996 (years with no estimate) was completed by linear interpolation of the values for 1986 and 1997 (dashed lines); values for the Czech Republic (CZE), the Slovak Republic (SVK) and Slovenia (SVN) are calculated with data from the Human Fertility Database (HFD), three-year moving averages. 
There are only minor differences in comparison to the values for Slovenia in the 1980 s as well as since the beginning of the 21 st century. During the 1990s, the much less pronounced fertility reduction shown by the TFR* in comparison to the conventional TFR fits the examples of the Czech and Slovak Republics very well. Both experienced declines in the conventional TFR similar to those occurring in Eastern Germany during this period.

\section{Discussion}

As already mentioned in the introduction, the main aim of the work for this article was the compilation of a time series of estimates for the tempo-adjusted total fertility rate in Western and Eastern Germany. To achieve this, we used a variety of data sources from which age- and parity-specific birth numbers could be derived to serve as basis for estimating the tempo-adjusted TFR*. It was possible to construct a complete time series for Western Germany for the years from 1960 to 2007. For Eastern Germany, however, it was not possible to provide such a complete time series. We were able to present estimates (by means of three year averages) for the years 1956 to 1986 and for 1997 to 2007 (the estimates for single calendar years cover the years 1959-2008 for Western Germany and the years 1955-1987 as well as 1996-2008 for Eastern Germany).

Although the idea behind Bongaarts and Feeney's tempo approach (not only for fertility but also for all other demographic events) as well as the arguments of the critics are described in Luy (2010), we should add a few remarks with regard to the interpretation and correct attribution of the tempo-adjusted time series presented in this paper. Particularly the question of the interpretation of the tempo-adjusted total fertility rate is not easy to answer, and has already led to a number of misunderstandings in the corresponding demographic literature. The advantage of the conventional TFR is its clear definition and interpretation as the sum of the age-specific fertility rates observed in a given calendar year. In order to explain the meaning of the TFR* as intended by Bongaarts and Feeney, it is necessary to describe this indicator in a broader context.

Independent of the calculation variant (conventional or tempo-adjusted), the aim of the calculation of the total fertility rate for a period is to provide a cross-sectional measure of a population's current fertility. Therefore, only women who are aged between 15 and 49 in the calendar year under observation, i.e. women hence belonging to 35 different cohorts, are considered. The current fertility of these women is influenced to differing degrees by the current political and societal framework and their own reproduction histories. In order to obtain a better understanding of a period measure, one might imagine that the current age-specific fertility conditions are used to construct a scenario for a hypothetical population. All the women of this hypothetical population would realise precisely the given age-specific fertility at any time. In such a scenario, all female cohorts would have the same final average number of children, which equals the average number of children of all women 
aged between 15 and 49 living in each calendar year. Demographers refer to such a scenario as a "stable population".

A real population whose current fertility is to be characterised by the total fertility rate is naturally never stable. Consequently, period indicators derived in the logic of the stable population always have to be regarded as purely hypothetical. The idea behind Bongaarts and Feeney's tempo approach is based on the fact that the number of births and the number of women aged between 15 to 49 living in a specific calendar year do not originate from a stable population. Imagine a rather simple exemplary case in which each woman has exactly one child, gives birth at exactly the same age, and that the times of the births are evenly distributed over the year. In this scenario, the sum of the age-specific fertility rates as an indicator of the current fertility would also be exactly one child per woman in any given calendar year. If, however, the age at which the women give birth to their child continually increases (so that a change in birth timing takes place, but not in birth quantum), the cohorts of women being in reproductive ages in a calendar year would have their children over a longer period than one year. In this case, all women living in a specific calendar year would still realise one birth during their lives, but the average value derived from the age-specific fertility rates for this year would be lower than one.

Bongaarts and Feeneys' approach for characterising the fertility of a specific calendar year takes into account that the current fertility of a real population does not originate from a situation in which the age at childbirth of all cohorts currently living remains unchanged. The idea is hence to adjust the time frames of the birth times of the newborns and of the cohorts of mothers (i.e. the numerators and denominators of the age-specific fertility rates) to capture the current birth quantum of the currently living women. The adjustment relates exclusively to the above described expansion effect of the birth period resulting from the increase in the age at childbirth, assuming that the fertility quantum remains unchanged despite the age shift (analogously, when the age at childbirth declines, the reduction effect of the shorter childbirth period would be adjusted for).

In a stable population, the total fertility rate of a calendar year can be regarded as the average number of children born during the life course of all female cohorts currently living. In these terms, the conventional period TFR (i.e. the observed total fertility rate of a specific calendar year) can also be interpreted as the average number of children born by the female cohorts living at the same time in the hypothetical population in the course of their reproductive life span. The prerequisite is that these female cohorts realise exactly the age-specific fertility rates observed in the period, i.e. without changes in birth quantum and birth timing. The tempo-adjusted TFR* is to be equivalently interpreted as the average number of children who are born to the hypothetical female cohorts living at the same time in the course of their reproductive life span if these female cohorts realise the birth quantum of the period observed, defined by the age-specific fertility rates, but with changes in birth timing. When we reduce the interpretation to the single hypothetical cohort usually used, then the TFR* does not reflect the age-specific fertility rates observed in the period, but the age-specific fertility rates adjusted for changes in the birth timing during the observed year (see also Lesthaeghe/Willems 1999). 
Besides the aspects of birth quantum and birth timing, the age distribution of the parity-specific fertility rates by the age of the women is also relevant with regard to the tempo adjustment according to the Bongaarts and Feeney formula used in this article. It becomes evident from equation (6) that the tempo adjustment is exclusively based on the change in the average age at childbirth of the parities. Thus, the Bongaarts and Feeney formula implies that the distribution of the age-specific fertility rates remains constant when shifting with age. Most of the methodical critics of tempo adjustment focus on this feature of the Bongaarts and Feeney method (see e.g. van Imhoff/Keilman 2000; Kohler/Philipov 2001; van Imhoff 2001; Yi/Land 2001). In real populations, the changes in the average age at childbirth are indeed accompanied by variance changes which also exert an influence on the number of children born in a calendar year. Thus, the increase in the average age at childbirth can be caused by both an increase in age-specific fertility in the higher reproductive age and by a fall in the fertility rates among younger women (in the first case, the fertility quantum would increase in the long term; in the latter it would fall). Consequently, very different changes in the age distribution of the parity-specific fertility rates can lead to identical changes in the average age at childbirth, and hence to an identical tempo adjustment with the Bongaarts and Feeney formula. Such cases are not rare and can also be observed in the German population during the calendar years analysed in this paper.

Theoretically it is possible to extend the tempo adjustment to include the effect of changes in the age distribution of the parity-specific fertility rates as proposed by Kohler and Philipov (2001). In practice, however, feasibility reaches its limit here in most cases because of the detailed nature of the data required. It is therefore important to note that the tempo adjustment with the Bongaarts and Feeney formula is merely an approximation of the intended adjustment of the total fertility rate (see Luy 2010 for details). However, the criticism of the non-consideration of variance effects can be countered by two arguments: The first concerns the relative significance of changes in the average age at childbirth and in the age distribution of the age-specific fertility rates for the numbers of births occurring in a specific calendar year. As Dinkel (1989) has shown by simulations, changes in the average age at childbirth have a much larger impact on the birth numbers than changes in the variance of the fertility distribution. It is not likely that the non-consideration of variance changes leading to an incorrect direction of the tempo adjustment with the Bongaarts and Feeney formula occurs frequently, albeit its absolute extent can indeed be distorted. The second argument is that the conventional TFR does not at all account for changes in birth timing. Consequently, also Kohler and Philipov (2001) concluded that an adjustment of the total fertility rate with the Bongaarts and Feeney formula is better for the analysis of period fertility than completely excluding tempo adjustment.

This discussion, however, is not aimed to ascertain which measure is better suited to characterise period fertility. One should not forget that the TFR and the $\mathrm{TFR}^{*}$ are both pure period indicators, and hence both solely reflect hypothetical average birth numbers. In case of the conventional TFR, this hypothetical average birth number is based on the observed fertility rates of a calendar year, and in the 
case of the tempo-adjusted TFR* on the estimated birth quantum of the women living in this calendar year. The latter cannot be measured, but only modelled, which is certainly a weakness of the TFR* compared to the conventional total fertility rate. Ultimately, the two indicators are based on somewhat different reference quantities. For the analysis of period fertility it is thus most informative to use them parallel and supplementing one another, as it was done in all the papers listed in the introduction.

Regarding the empirical results presented in this article, it can be stated that the two fertility indicators - the conventional TFR and the tempo-adjusted TFR* identify different phases in fertility trends in Western and Eastern Germany. In both parts of the country, the TFR* is lower than the TFR until the end of the 1960s. This is a consequence of the decline in the average age at childbirth, in particular with regard to the first and second births. The age of the women at the birth of their children rises markedly in Western Germany in the 1970s and 1980s. As a consequence, the tempo-adjusted TFR* is on average almost 0.18 higher than the conventional TFR during the years from 1971 to 1987. In the former GDR, by contrast, the age at childbirth remained relatively constant in this period, so that the tempo-adjusted $\mathrm{TFR}^{*}$ and the conventional TFR do not differ significantly. Since the beginning of the 1990s, the average age at childbirth of Western German women rises once more after a brief phase of relative stability. This trend causes an increasing deviation between the estimated TFR* and the conventional TFR in Western Germany. In Eastern Germany, we can only presume that the difference between the two indicators was particularly large in the first half of the 1990s. This is suggested by several indicators pointing towards a rapid increase in the age at childbirth of Eastern German mothers. An idea of the extent of this difference is provided by the estimates for the second half of the 1990s. The difference between the tempo-adjusted TFR* and the conventional TFR in the years 1997-1999 is between 0.37 and 0.43. In the years from 2000 to 2007, the TFR* in Eastern Germany is on average 0.28 higher than the conventional TFR.

Hence, the combined picture of the conventional TFR and the tempo-adjusted $\mathrm{TFR}^{*}$ provides interesting results with regard to the trends in period fertility in Western and Eastern Germany, which were not analysed in detail in this paper. This applies above all to the West-East differences in the overall trend and the massive tempo effects in Eastern Germany during the 1990s. Since 2009 it is possible to analyse level and trends of fertility in Germany with tempo-adjusted fertility rates on the basis of parity-specific data for all births from official statistics. For the period prior to this we have compiled the best possible estimates. Even if these estimates are not comparable with the data of official statistics in qualitative terms, the data presented in this paper enables researchers to include the population of Western and Eastern Germany in future research on international trends in tempo-adjusted period fertility. 


\section{References}

Arránz Becker, Oliver; Lois, Daniel; Nauck, Bernhard 2010: Differences in fertility patterns between East and West German women. Disentangling the roles of cultural background and of the transformation process. In: Comparative Population Studies - Zeitschrift für Bevölkerungswissenschaft 35,1: 7-34 [doi: 10.4232/10.CPoS-2010-02en].

Beck-Gernsheim, Elisabeth 1997: Geburtenrückgang und Kinderwunsch - die Erfahrung in Ostdeutschland. In: Zeitschrift für Bevölkerungswissenschaft 22,1: 59-71.

Bernardi, Laura; Keim, Sylvia 2007: Anfang dreißig und noch kinderlos? Lebenswege und Familienmodelle berufstätiger Frauen aus Ost- und Westdeutschland. In: Konietzka, Dirk; Kreyenfeld, Michaela (Eds.): Ein Leben ohne Kinder. Kinderlosigkeit in Deutschland. Wiesbaden: VS Verlag für Sozialwissenschaften: 317-334.

Bernardi, Laura; Klärner, Andreas; von der Lippe, Holger 2008: Job insecurity and the timing of parenthood: a comparison between Eastern and Western Germany. In: European Journal of Population 24,3: 287-313 [doi:10.1007/s10680-007-9127-5].

BGBI (Bundesgesetzblatt) 2007: Gesetz zur Änderung des Mikrozensusgesetzes 2005 und des Bevölkerungsstatistikgesetzes vom 30. Oktober 2007. BGBI Jahrgang 2007, Teil I, Nr. 55.

Birg, Herwig; Filip, Detlef; Flöthmann, E.-Jürgen 1990: Paritätsspezifische Kohortenanalyse des generativen Verhaltens in der Bundesrepublik Deutschland nach dem 2. Weltkrieg. IBS-Materialien 30. Bielefeld: Institut für Bevölkerungsforschung und Sozialpolitik.

Boehnke, Mandy 2007: Hochschulbildung und Kinderlosigkeit: Deutsch-deutsche Unterschiede. In: Konietzka, Dirk; Kreyenfeld, Michaela (Eds.): Ein Leben ohne Kinder. Kinderlosigkeit in Deutschland. Wiesbaden: VS Verlag für Sozialwissenschaften, 295-315.

Bongaarts, John; Feeney, Griffith 1998: On the quantum and tempo of fertility. In: Population and Development Review 24, 2: 271-291.

Bongaarts, John; Feeney, Griffith 2006: The quantum and tempo of life-cycle events. In: Vienna Yearbook of Population Research 2006: 115-151 [doi: 10.1553/populationyearbook2006s115].

Bongaarts, John; Feeney, Griffith 2010: When is a tempo effect a tempo distortion? In: Genus 66, 2: 1-15.

Butterwege, Christoph; Klundt, Michael; Zeng, Matthias 2005: Kinderarmut in Ost- und Westdeutschland. Wiesbaden: VS Verlag für Sozialwissenschaften.

Conrad, Christoph; Lechner, Michael; Welf, Werner 1996: East German fertility after unification: crisis or adaptation? In: Population and Development Review 22,2: 331-358.

Dinkel, Reiner H. 1989: Demographie. Band 1: Bevölkerungsdynamik. München: Vahlen.

Dorbritz, Jürgen 1992: Nuptialität, Fertilität und familiale Lebensformen in der sozialen Transformation - Übergang zu einer neuen Bevölkerungsweise in Ostdeutschland? In: Zeitschrift für Bevölkerungswissenschaft 18,2: 167-196.

Dorbritz, Jürgen 1997: Der demographische Wandel in Ostdeutschland - Verlauf und Erklärungsansätze. In: Zeitschrift für Bevölkerungswissenschaft 22,2/3: 239-268.

Dorbritz, Jürgen; Schwarz, Karl 1996: Kinderlosigkeit in Deutschland - ein Massenphänomen? Analysen zu Erscheinungsformen und Ursachen. In: Zeitschrift für Bevölkerungswissenschaft 21,3: 231-261. 
Dornseiff, Jann-Michael; Sackmann, Reinhold 2003: Familien-, Erwerbs- und Fertilitätsdynamiken in Ost- und Westdeutschland. In: Bien, Walter; Marbach, Jan H. (Eds.): Partnerschaft und Familiengründung. Ergebnisse der dritten Welle des Familien-Survey. Opladen: Leske+Budrich: 309-348.

Eberstadt, Nicholas 1994: Demographic shocks after communism: eastern Germany, 1989-93. In: Population and Development Review 20,1: 137-152.

Eckhard, Jan 2006: Kinderlosigkeit durch Partnerschaftslosigkeit. Der Wandel der Partnerschaftsbiographien und Zusammenhänge mit der Geburtenentwicklung. In: Zeitschrift für Bevölkerungswissenschaft 31,1: 105-126.

Frejka, Tomas; Sobotka, Tomáš 2008: Fertility in Europe: diverse, delayed and below replacement. In: Demographic Research 19 (Special Issue, Childbearing trends and policies in Europe), 3: 15-46 [doi:10.4054/DemRes.2008.19.3].

Goerke, K.; Lack, N. 2000: Qualitätssicherung in der Geburtshilfe - Perinatalerhebung. In: Der Gynäkologe 33,3: 220-224 [doi: 10.1007/s001290050538].

Goldstein, Joshua R.; Lutz, Wolfgang; Scherbov, Sergei 2003: Long-term population decline in Europe: the relative importance of tempo effects and generational length. In: Population and Development Review 29,4: 699-707 [doi/10.1111/j.17284457.2003.00699.x].

Goldstein, Joshua R.; Sobotka, Tomáš; Jasilioniene, Aiva 2009: The end of "lowest-low" fertility? In: Population and Development Review 35, 4: 663-699.

Hajnal, John 1947: The analysis of birth statistics in the light of the recent international recovery of the birth-rate. In: Population Studies 1,2: 137-164.

Hank, Karsten 2002: Regional social contexts and individual fertility decisions: a multilevel analysis of first and second births in Western Germany. In: European Journal of Population 18,3: 263-279 [doi: 10.1023/A:1019765026537].

Hank, Karsten; Kreyenfeld, Michaela 2003: A multilevel analysis of child care and women's fertility decisions in Western Germany. In: Journal of Marriage and Family 65,3: 584-596.

Hank, Karsten; Kreyenfeld, Michaela; Spieß, C. Katharina 2004: Kinderbetreuung und Fertilität in Deutschland. In: Zeitschrift für Soziologie 33,3: 228-244.

Human Fertility Database. Max-Planck-Institut für demografische Forschung (Deutschland) und Vienna Institute of Demography (Österreich). Abrufbar unter www.humanfertility.org (Daten-Download am 02.12.2010).

Kohler, Hans-Peter; Billari, Francesco C.; Ortega, José A. 2002: The emergence of lowest-low fertility in Europe during the 1990s. In: Population and Development Review 28,4: 641-680.

Kohler, Hans-Peter; Philipov, Dimiter 2001: Variance effects in the Bongaarts-Feeney formula. In: Demography 38,1: 1-16.

Kreyenfeld, Michaela 2002: Parity specific birth rates for West Germany: an attempt to combine survey data and vital statistics. In: Zeitschrift für Bevölkerungswissenschaft 27,3: 327-357.

Kreyenfeld, Michaela 2003: Crises or adaption - reconsidered: a comparison of East and West German fertility patterns in the first six years after the 'Wende'. In: European Journal of Population 19,3: 303-329.

Kreyenfeld, Michaela 2009: Das zweite Kind in Ostdeutschland: Aufschub oder Verzicht? In: Cassens, Insa; Luy, Marc; Scholz, Rembrandt D. (Eds.): Die Bevölkerung in Ost- und Westdeutschland. Demografische, gesellschaftliche und wirtschaftliche Entwicklungen seit der Wende. Wiesbaden: VS Verlag für Sozialwissenschaften: 100-123. 
Kreyenfeld, Michaela; Scholz, Rembrandt; Peters, Frederik; Wlosnewski, Ines 2010: Order-specific fertility rates for Germany. Estimates from perinatal statistics for the period 2001-2008. In: Comparative Population Studies - Zeitschrift für Bevölkerungswissenschaft 35,2: 207-224 [doi: 10.4232/10.CPoS-2010-06en].

Lechner, Michae/ 2001: The empirical analysis of East German fertility after unification: an update. In: European Journal of Population 17,1: 61-74.

Lesthaeghe, Ron; Willems, Paul 1999: Is low fertility a temporary phenomenon in the European Union? In: Population and Development Review 25,2: 211-228.

Luy, Marc 2009: Empirische Bestandsaufnahme der Bevölkerungsentwicklung in Ostund Westdeutschland. In: Schubarth, Wilfried; Speck, Karsten (Hrsg.): Regionale Abwanderung Jugendlicher. Theoretische Analysen, empirische Befunde und politische Gegenstrategien. Weinheim, München: Juventa: 43-67.

Luy, Marc 2010: Tempo effects and their relevance in demographic analysis. In: Comparative Population Studies - Zeitschrift für Bevölkerungswissenschaft 35,3: 415-446 [doi: 10.4232/10.CPoS-2010-11en].

Menning, Sonja 1995: Geburten- und Heiratsverzicht in den neuen Ländern - Abschied von der Familie? In: Sydow, Hubert; Schlegel, Uta; Helmke, Andreas (Hrsg.): Chancen und Risiken im Lebenslauf: Beiträge zum gesellschaftlichen Wandel in Ostdeutschland. Berlin: Akademie Verlag: 137-150.

Philipov, Dimiter; Kohler, Hans-Peter 2001: Tempo effects in the fertility decline in eastern Europe: evidence from Bulgaria, the Czech Republic, Hungary, Poland, and Russia. In: European Journal of Population 17,1: 37-60.

Pötzsch, Olga 2010: Annahmen zur Geburtenentwicklung in der 12. koordinierten Bevölkerungsvorausberechnung. In: Wirtschaft und Statistik 1/2010: 29-40.

Sackmann, Reinhold 1999: Ist ein Ende der Fertilitätskrise in Ostdeutschland absehbar? In: Zeitschrift für Bevölkerungswissenschaft 24,2: 187-211.

Sobotka, Tomáš 2002: Comments on „The empirical analysis of East German fertility after unification: an update“. In: European Journal of Population 18,3: 203-208.

Sobotka, Tomáš 2003: Tempo-quantum and period-cohort interplay in fertility changes in Europe. Evidence from the Czech Republic, Italy, the Netherlands and Sweden. In: Demographic Research 8,6: 152-214 [doi: 10.4054/DemRes.2003.8.6].

Sobotka, Tomáš 2004a: Is lowest-low fertility in Europe explained by the postponement of childbearing? In: Population and Development Review 30,2: 195-220.

Sobotka, Tomáš 2004b: Postponement of childbearing and low fertility in Europe. Amsterdam: Dutch University Press.

Sobotka, Tomáš; Lutz, Wolfgang 2010: Misleading policy messages derived from the period TFR: Should we stop using it? In: Comparative Population Studies - Zeitschrift für Bevölkerungswissenschaft 35,3: 637-664 [doi: 10.4232/10.CPoS-2010-15en].

Statistisches Bundesamt 2008: Natürliche Bevölkerungsbewegung, Fachserie 1, Reihe 1.1. Wiesbaden: Statistisches Bundesamt.

Statistisches Bundesamt 2010: Babys in den neuen Ländern haben jüngere Mütter. Pressemitteilung vom 2. Dezember 2010 sowie Tabellen unter: http://www.destatis.de/ jetspeed/portal/cms/Sites/destatis/Internet/DE/Navigation/Statistiken/Bevoelkerung/ GeburtenSterbefaelle/Tabellen.psml.

Van Imhoff, Evert 2001: On the impossibility of inferring cohort fertility measures from period fertility measures. In: Demographic Research 5,2: 23-64 [doi: 10.4054/ DemRes.2001.5.2]. 
Van Imhoff, Evert; Keilman, Nico 2000: On the quantum and tempo of fertility: comment. In: Population and Development Review 26,3: 549-553.

Witte, James C.; Wagner, Gert 1995: Declining fertility in East Germany after unification: a demographic response to socioeconomic change. In: Population and Development Review 21,2: 387-397.

Yi, Zeng; Land, Kenneth C. 2001: A sensitivity analysis of the Bongaarts-Feeney method for adjusting bias in observed period total fertility rates. In: Demography 38,1: 17-28.

Translated from the original text by the Federal Institute for Population Research. The reviewed and authors" authorised original article in German is available under the title "Schätzung der tempobereinigten Geburtenziffer für West- und Ostdeutschland, 1955-2008", DOI 10.4232/10.CPoS2010-14de or URN urn:nbn:de:bib-cpos-2010-14de3, at http://www.comparativepopulationstudies.de.

Date of submission: 20.12.2010

Date of acceptance: 26.12 .2010

Dr. Marc Luy $(\varangle)$. Vienna Institute of Demography of the Austrian Academy of Sciences, Wittgenstein Centre for Demography and Global Human Capital, A-1040 Vienna, Austria. E-Mail: mail@marcluy.eu URL: http://www.marcluy.eu

Olga Pötzsch. Federal Statistical Office, Gustav-Stresemann-Ring 11, 65189 Wiesbaden, Germany. E-Mail: olga.poetzsch@destatis.de,

URL: http://www.destatis.de 
Estimates of the Tempo-adjusted Total Fertility Rate in Western and Eastern Germany $\quad 633$

Annex 1: Estimated subdivision of the conventional total fertility rate TFR for Western and Eastern Germany into the parity-specific TFR $\mathrm{T}_{\mathrm{i}}$, 1954-2009

\begin{tabular}{|c|c|c|c|c|c|c|c|c|c|c|}
\hline \multirow[b]{2}{*}{ Year } & \multicolumn{5}{|c|}{ Western Germany } & \multicolumn{5}{|c|}{ Eastern Germany } \\
\hline & $\mathrm{TFR}_{1}$ & $\mathrm{TFR}_{2}$ & $\mathrm{TFR}_{3}$ & $\mathrm{TFR}_{4+}$ & TFR & $\mathrm{TFR}_{1}$ & $\mathrm{TFR}_{2}$ & $\mathrm{TFR}_{3}$ & $\mathrm{TFR}_{4+}$ & TFR \\
\hline 1954 & -- & -- & -- & -- & 2.10 & 0.93 & 0.71 & 0.36 & 0.35 & 2.35 \\
\hline 1955 & -- & -- & -- & -- & 2.11 & 0.93 & 0.71 & 0.37 & 0.35 & 2.35 \\
\hline 1956 & -- & -- & -- & -- & 2.20 & 0.88 & 0.68 & 0.37 & 0.36 & 2.26 \\
\hline 1957 & -- & -- & -- & -- & 2.30 & 0.85 & 0.66 & 0.36 & 0.36 & 2.21 \\
\hline 1958 & 0.94 & 0.67 & 0.37 & 0.31 & 2.29 & 0.85 & 0.65 & 0.36 & 0.37 & 2.21 \\
\hline 1959 & 0.97 & 0.69 & 0.39 & 0.33 & 2.37 & 0.89 & 0.67 & 0.38 & 0.41 & 2.35 \\
\hline 1960 & 0.97 & 0.69 & 0.38 & 0.32 & 2.37 & 0.90 & 0.65 & 0.37 & 0.41 & 2.33 \\
\hline 1961 & 1.00 & 0.72 & 0.40 & 0.34 & 2.46 & 0.95 & 0.66 & 0.38 & 0.43 & 2.40 \\
\hline 1962 & 1.00 & 0.71 & 0.39 & 0.34 & 2.44 & 0.97 & 0.66 & 0.36 & 0.43 & 2.42 \\
\hline 1963 & 1.02 & 0.74 & 0.41 & 0.35 & 2.52 & 0.99 & 0.68 & 0.37 & 0.43 & 2.47 \\
\hline 1964 & 1.02 & 0.75 & 0.41 & 0.35 & 2.54 & 0.99 & 0.69 & 0.37 & 0.44 & 2.51 \\
\hline 1965 & 1.02 & 0.75 & 0.40 & 0.34 & 2.51 & 1.00 & 0.70 & 0.36 & 0.42 & 2.48 \\
\hline 1966 & 1.04 & 0.75 & 0.41 & 0.33 & 2.53 & 0.98 & 0.70 & 0.36 & 0.38 & 2.42 \\
\hline 1967 & 1.03 & 0.75 & 0.39 & 0.31 & 2.49 & 0.96 & 0.69 & 0.35 & 0.34 & 2.34 \\
\hline 1968 & 0.99 & 0.72 & 0.37 & 0.29 & 2.38 & 0.95 & 0.69 & 0.34 & 0.31 & 2.30 \\
\hline 1969 & 0.93 & 0.67 & 0.34 & 0.26 & 2.21 & 0.96 & 0.68 & 0.33 & 0.27 & 2.24 \\
\hline 1970 & 0.88 & 0.61 & 0.30 & 0.22 & 2.02 & 0.98 & 0.67 & 0.30 & 0.24 & 2.19 \\
\hline 1971 & 0.86 & 0.59 & 0.28 & 0.20 & 1.92 & 0.97 & 0.66 & 0.29 & 0.22 & 2.14 \\
\hline 1972 & 0.78 & 0.53 & 0.24 & 0.17 & 1.71 & 0.90 & 0.54 & 0.19 & 0.14 & 1.79 \\
\hline 1973 & 0.70 & 0.48 & 0.21 & 0.15 & 1.54 & 0.88 & 0.48 & 0.12 & 0.09 & 1.58 \\
\hline 1974 & 0.70 & 0.48 & 0.19 & 0.13 & 1.51 & 0.87 & 0.48 & 0.11 & 0.08 & 1.54 \\
\hline 1975 & 0.68 & 0.46 & 0.19 & 0.12 & 1.45 & 0.87 & 0.50 & 0.10 & 0.07 & 1.54 \\
\hline 1976 & 0.68 & 0.47 & 0.18 & 0.11 & 1.45 & 0.90 & 0.55 & 0.11 & 0.07 & 1.64 \\
\hline 1977 & 0.67 & 0.46 & 0.17 & 0.10 & 1.40 & 0.96 & 0.68 & 0.13 & 0.07 & 1.85 \\
\hline 1978 & 0.66 & 0.46 & 0.17 & 0.09 & 1.38 & 0.99 & 0.70 & 0.14 & 0.07 & 1.90 \\
\hline 1979 & 0.65 & 0.46 & 0.17 & 0.09 & 1.38 & 0.98 & 0.70 & 0.14 & 0.07 & 1.89 \\
\hline 1980 & 0.69 & 0.48 & 0.18 & 0.09 & 1.44 & 1.01 & 0.70 & 0.16 & 0.07 & 1.94 \\
\hline 1981 & 0.69 & 0.48 & 0.19 & 0.09 & 1.44 & 0.95 & 0.69 & 0.15 & 0.07 & 1.85 \\
\hline 1982 & 0.68 & 0.47 & 0.18 & 0.08 & 1.41 & 0.93 & 0.70 & 0.16 & 0.07 & 1.86 \\
\hline 1983 & 0.64 & 0.45 & 0.17 & 0.07 & 1.33 & 0.89 & 0.67 & 0.16 & 0.07 & 1.79 \\
\hline 1984 & 0.61 & 0.44 & 0.17 & 0.07 & 1.29 & 0.85 & 0.65 & 0.16 & 0.07 & 1.74 \\
\hline 1985 & 0.61 & 0.44 & 0.17 & 0.07 & 1.28 & 0.83 & 0.64 & 0.19 & 0.08 & 1.73 \\
\hline 1986 & 0.66 & 0.48 & 0.15 & 0.06 & 1.35 & 0.81 & 0.63 & 0.18 & 0.08 & 1.70 \\
\hline 1987 & 0.67 & 0.47 & 0.16 & 0.06 & 1.37 & 0.81 & 0.65 & 0.20 & 0.08 & 1.74 \\
\hline 1988 & 0.69 & 0.49 & 0.17 & 0.07 & 1.41 & 0.78 & 0.62 & 0.19 & 0.08 & 1.67 \\
\hline 1989 & 0.69 & 0.48 & 0.17 & 0.07 & 1.40 & -- & -- & -- & -- & 1.57 \\
\hline 1990 & 0.71 & 0.49 & 0.17 & 0.07 & 1.45 & -- & -- & -- & -- & 1.52 \\
\hline 1991 & 0.71 & 0.47 & 0.17 & 0.07 & 1.42 & -- & -- & -- & -- & 0.98 \\
\hline 1992 & 0.70 & 0.47 & 0.17 & 0.07 & 1.40 & -- & -- & -- & -- & 0.83 \\
\hline 1993 & 0.69 & 0.47 & 0.17 & 0.06 & 1.39 & -- & -- & -- & -- & 0.77 \\
\hline
\end{tabular}


Annex 1 (continuation)

\begin{tabular}{cccccc|ccccc}
\hline & \multicolumn{7}{c|}{ Western Germany } & \multicolumn{5}{c}{ Eastern Germany } \\
\cline { 2 - 10 } Year & TFR $_{1}$ & TFR $_{2}$ & TFR $_{3}$ & TFR $_{4+}$ & TFR & TFR $_{1}$ & TFR $_{2}$ & TFR $_{3}$ & TFR $_{4+}$ & TFR \\
\hline 1994 & 0.68 & 0.45 & 0.16 & 0.06 & 1.35 & -- & -- & -- & -- & 0.77 \\
1995 & 0.67 & 0.45 & 0.16 & 0.06 & 1.34 & 0.42 & 0.28 & 0.09 & 0.05 & 0.84 \\
1996 & 0.66 & 0.50 & 0.17 & 0.08 & 1.40 & 0.49 & 0.31 & 0.09 & 0.06 & 0.95 \\
1997 & 0.70 & 0.49 & 0.17 & 0.08 & 1.44 & 0.53 & 0.35 & 0.11 & 0.05 & 1.04 \\
1998 & 0.69 & 0.49 & 0.16 & 0.07 & 1.41 & 0.58 & 0.35 & 0.11 & 0.05 & 1.09 \\
1999 & 0.69 & 0.48 & 0.16 & 0.08 & 1.41 & 0.62 & 0.36 & 0.11 & 0.06 & 1.15 \\
2000 & 0.68 & 0.51 & 0.16 & 0.06 & 1.41 & 0.66 & 0.38 & 0.11 & 0.06 & 1.21 \\
2001 & 0.68 & 0.48 & 0.15 & 0.07 & 1.38 & 0.68 & 0.39 & 0.11 & 0.06 & 1.23 \\
2002 & 0.68 & 0.47 & 0.15 & 0.07 & 1.37 & 0.69 & 0.40 & 0.11 & 0.05 & 1.24 \\
2003 & 0.67 & 0.48 & 0.15 & 0.07 & 1.36 & 0.69 & 0.41 & 0.11 & 0.05 & 1.26 \\
2004 & 0.67 & 0.48 & 0.16 & 0.07 & 1.37 & 0.71 & 0.42 & 0.12 & 0.06 & 1.31 \\
2005 & 0.66 & 0.48 & 0.15 & 0.07 & 1.36 & 0.70 & 0.42 & 0.12 & 0.06 & 1.30 \\
2006 & 0.65 & 0.47 & 0.16 & 0.07 & 1.34 & 0.69 & 0.43 & 0.13 & 0.06 & 1.30 \\
2007 & 0.67 & 0.47 & 0.16 & 0.07 & 1.37 & 0.72 & 0.46 & 0.13 & 0.06 & 1.37 \\
2008 & 0.67 & 0.47 & 0.16 & 0.07 & 1.37 & 0.73 & 0.47 & 0.14 & 0.07 & 1.40 \\
2009 & 0.67 & 0.45 & 0.15 & 0.07 & 1.35 & 0.72 & 0.48 & 0.14 & 0.07 & 1.40 \\
\hline
\end{tabular}

Notes: -- no estimates available; data basis of the estimates for Western Germany for the years 1958-1985 Birg et al. (1990), 1986-1995 Kreyenfeld (2002), 1996-1999 perinatal survey, 2000 official statistics (marital births), 2001-2008 Kreyenfeld et al. (2010), 2009 official statistics (all births); data basis of the estimates for Eastern Germany for the years 1954-1988 official statistics of the GDR, 1995-2000 perinatal survey, 2001-2008 Kreyenfeld et al. (2010), 2009 official statistics (all births); deviations between the sum of the parityspecific TFRi and the total TFR are caused by rounding errors. 
Annex 2: Estimated subdivision of the tempo-adjusted total fertility rate TFR* for Western and Eastern Germany into the parity-specific $\mathrm{TFR}_{\mathrm{i}}{ }^{*} \mathrm{~s}$, 1954-2009 (annual values)

\begin{tabular}{|c|c|c|c|c|c|c|c|c|c|c|}
\hline \multirow[b]{2}{*}{ Year } & \multicolumn{5}{|c|}{ Western Germany } & \multicolumn{5}{|c|}{ Eastern Germany } \\
\hline & $\mathrm{TFR}_{1}{ }^{*}$ & $\mathrm{TFR}_{2}{ }^{*}$ & $\mathrm{TFR}_{3}{ }^{*}$ & $\mathrm{TFR}_{4+}{ }^{*}$ & TFR* & $\mathrm{TFR}_{1}{ }^{*}$ & $\mathrm{TFR}_{2}{ }^{*}$ & $\mathrm{TFR}_{3}{ }^{*}$ & $\mathrm{TFR}_{4+}{ }^{*}$ & $\mathrm{TFR}^{*}$ \\
\hline 1954 & -- & -- & -- & -- & -- & -- & -- & -- & -- & -- \\
\hline 1955 & -- & -- & -- & -- & -- & 0.82 & 0.67 & 0.31 & 0.26 & 2.16 \\
\hline 1956 & -- & -- & -- & -- & -- & 0.81 & 0.60 & 0.32 & 0.27 & 2.08 \\
\hline 1957 & -- & -- & -- & -- & -- & 0.80 & 0.61 & 0.33 & 0.30 & 2.10 \\
\hline 1958 & -- & -- & -- & -- & -- & 0.72 & 0.60 & 0.34 & 0.33 & 2.03 \\
\hline 1959 & 0.86 & 0.64 & 0.37 & 0.30 & 2.19 & 0.75 & 0.61 & 0.37 & 0.38 & 2.15 \\
\hline 1960 & 0.84 & 0.62 & 0.36 & 0.30 & 2.15 & 0.81 & 0.58 & 0.37 & 0.40 & 2.17 \\
\hline 1961 & 0.87 & 0.63 & 0.36 & 0.33 & 2.20 & 0.87 & 0.56 & 0.36 & 0.43 & 2.23 \\
\hline 1962 & 0.90 & 0.63 & 0.36 & 0.34 & 2.22 & 0.92 & 0.60 & 0.36 & 0.44 & 2.31 \\
\hline 1963 & 0.92 & 0.68 & 0.38 & 0.36 & 2.32 & 0.94 & 0.66 & 0.36 & 0.47 & 2.40 \\
\hline 1964 & 0.93 & 0.69 & 0.40 & 0.38 & 2.37 & 0.95 & 0.63 & 0.34 & 0.46 & 2.35 \\
\hline 1965 & 0.92 & 0.66 & 0.38 & 0.35 & 2.30 & 0.97 & 0.63 & 0.32 & 0.40 & 2.35 \\
\hline 1966 & 0.94 & 0.68 & 0.38 & 0.34 & 2.33 & 0.97 & 0.67 & 0.33 & 0.35 & 2.34 \\
\hline 1967 & 0.96 & 0.71 & 0.40 & 0.35 & 2.38 & 0.96 & 0.65 & 0.32 & 0.33 & 2.27 \\
\hline 1968 & 0.91 & 0.75 & 0.43 & 0.35 & 2.37 & 0.92 & 0.68 & 0.33 & 0.33 & 2.24 \\
\hline 1969 & 0.84 & 0.71 & 0.38 & 0.30 & 2.19 & 0.91 & 0.71 & 0.36 & 0.33 & 2.26 \\
\hline 1970 & 0.84 & 0.59 & 0.30 & 0.24 & 1.96 & 0.92 & 0.71 & 0.36 & 0.29 & 2.23 \\
\hline 1971 & 0.91 & 0.57 & 0.27 & 0.20 & 1.95 & 0.93 & 0.73 & 0.34 & 0.29 & 2.21 \\
\hline 1972 & 0.90 & 0.55 & 0.23 & 0.16 & 1.84 & 0.92 & 0.62 & 0.20 & 0.19 & 1.88 \\
\hline 1973 & 0.84 & 0.49 & 0.18 & 0.12 & 1.66 & 0.90 & 0.52 & 0.12 & 0.11 & 1.63 \\
\hline 1974 & 0.86 & 0.48 & 0.17 & 0.10 & 1.64 & 0.88 & 0.48 & 0.12 & 0.08 & 1.56 \\
\hline 1975 & 0.80 & 0.49 & 0.18 & 0.10 & 1.59 & 0.89 & 0.49 & 0.10 & 0.06 & 1.55 \\
\hline 1976 & 0.78 & 0.52 & 0.19 & 0.10 & 1.60 & 0.91 & 0.56 & 0.11 & 0.06 & 1.65 \\
\hline 1977 & 0.77 & 0.52 & 0.17 & 0.09 & 1.56 & 0.91 & 0.71 & 0.13 & 0.07 & 1.82 \\
\hline 1978 & 0.76 & 0.50 & 0.17 & 0.08 & 1.53 & 0.92 & 0.69 & 0.14 & 0.06 & 1.82 \\
\hline 1979 & 0.73 & 0.50 & 0.19 & 0.09 & 1.51 & 0.92 & 0.64 & 0.15 & 0.06 & 1.78 \\
\hline 1980 & 0.78 & 0.53 & 0.20 & 0.10 & 1.60 & 0.96 & 0.66 & 0.16 & 0.06 & 1.85 \\
\hline 1981 & 0.84 & 0.55 & 0.21 & 0.10 & 1.68 & 0.95 & 0.67 & 0.16 & 0.06 & 1.86 \\
\hline 1982 & 0.88 & 0.54 & 0.20 & 0.09 & 1.71 & 0.94 & 0.70 & 0.17 & 0.07 & 1.88 \\
\hline 1983 & 0.87 & 0.52 & 0.19 & 0.08 & 1.65 & 0.89 & 0.67 & 0.17 & 0.07 & 1.81 \\
\hline 1984 & 0.79 & 0.54 & 0.18 & 0.07 & 1.58 & 0.86 & 0.65 & 0.17 & 0.07 & 1.74 \\
\hline 1985 & 0.81 & 0.55 & 0.18 & 0.07 & 1.60 & 0.87 & 0.66 & 0.20 & 0.07 & 1.81 \\
\hline 1986 & 0.76 & 0.55 & 0.17 & 0.06 & 1.54 & 0.91 & 0.68 & 0.22 & 0.09 & 1.89 \\
\hline 1987 & 0.74 & 0.54 & 0.17 & 0.06 & 1.51 & 0.91 & 0.70 & 0.23 & 0.09 & 1.92 \\
\hline 1988 & 0.71 & 0.54 & 0.17 & 0.07 & 1.49 & -- & -- & -- & -- & -- \\
\hline 1989 & 0.70 & 0.52 & 0.17 & 0.07 & 1.45 & -- & -- & -- & -- & -- \\
\hline 1990 & 0.73 & 0.52 & 0.18 & 0.07 & 1.50 & -- & -- & -- & -- & -- \\
\hline 1991 & 0.74 & 0.50 & 0.17 & 0.07 & 1.47 & -- & -- & -- & -- & -- \\
\hline 1992 & 0.76 & 0.48 & 0.17 & 0.06 & 1.47 & -- & -- & -- & -- & -- \\
\hline 1993 & 0.79 & 0.51 & 0.16 & 0.06 & 1.53 & -- & -- & -- & -- & -- \\
\hline
\end{tabular}


Annex 2 (continuation)

\begin{tabular}{cccccc|ccccc}
\hline & \multicolumn{7}{c|}{ Western Germany } & \multicolumn{5}{c}{ Eastern Germany } \\
\cline { 2 - 10 } Year & TFR $_{1}{ }^{*}$ & TFR $_{2}{ }^{*}$ & TFR $_{3}{ }^{*}$ & TFR $_{4+}{ }^{*}$ & TFR $^{*}$ & TFR $_{1}{ }^{*}$ & TFR $_{2}{ }^{*}$ & TFR $_{3}{ }^{*}$ & TFR $_{4+}{ }^{*}$ & TFR $^{*}$ \\
\hline 1994 & 0.80 & 0.50 & 0.16 & 0.06 & 1.52 & -- & -- & -- & -- & -- \\
1995 & 0.72 & 0.52 & 0.15 & 0.07 & 1.47 & -- & -- & -- & -- & -- \\
1996 & 0.78 & 0.57 & 0.16 & 0.08 & 1.58 & 0.75 & 0.49 & 0.12 & 0.07 & 1.42 \\
1997 & 0.75 & 0.60 & 0.21 & 0.10 & 1.64 & 0.72 & 0.55 & 0.15 & 0.06 & 1.48 \\
1998 & 0.74 & 0.54 & 0.16 & 0.06 & 1.51 & 0.78 & 0.52 & 0.16 & 0.07 & 1.51 \\
1999 & 0.75 & 0.56 & 0.16 & 0.06 & 1.53 & 0.83 & 0.49 & 0.14 & 0.06 & 1.52 \\
2000 & 0.74 & 0.57 & 0.16 & 0.06 & 1.53 & 0.93 & 0.46 & 0.10 & 0.05 & 1.55 \\
2001 & 0.75 & 0.58 & 0.17 & 0.06 & 1.55 & 0.93 & 0.45 & 0.10 & 0.05 & 1.53 \\
2002 & 0.80 & 0.55 & 0.17 & 0.07 & 1.58 & 0.88 & 0.47 & 0.12 & 0.05 & 1.52 \\
2003 & 0.82 & 0.55 & 0.17 & 0.07 & 1.61 & 0.90 & 0.48 & 0.11 & 0.05 & 1.55 \\
2004 & 0.82 & 0.56 & 0.17 & 0.07 & 1.62 & 0.87 & 0.50 & 0.12 & 0.06 & 1.54 \\
2005 & 0.78 & 0.55 & 0.17 & 0.07 & 1.57 & 0.78 & 0.48 & 0.14 & 0.07 & 1.45 \\
2006 & 0.80 & 0.57 & 0.19 & 0.08 & 1.63 & 0.80 & 0.57 & 0.16 & 0.06 & 1.59 \\
2007 & 0.85 & 0.59 & 0.20 & 0.08 & 1.71 & 0.89 & 0.63 & 0.16 & 0.07 & 1.75 \\
2008 & 0.83 & 0.57 & 0.18 & 0.08 & 1.66 & 0.78 & 0.60 & 0.18 & 0.11 & 1.62 \\
2009 & -- & -- & -- & -- & -- & -- & -- & -- & -- & -- \\
\hline
\end{tabular}

Notes: -- no estimates available; data basis of the estimates for Western Germany for the years 1959-1984 Birg et al. (1990), 1985 combination Birg et al. (1990)/Kreyenfeld (2002), 1986-1994 Kreyenfeld (2002), 1995 combination Kreyenfeld (2002)/perinatal survey, 1996-1998 perinatal survey, 1999-2001 official statistics (marital births), 2002-2007 Kreyenfeld et al. (2010), 2008 combination Kreyenfeld et al. (2010)/official statistics (all births); data basis of the estimates for Eastern Germany for the years 1955-1987 official statistics of the GDR, 1996-1999 perinatal survey, 2000-2001 combination perinatal survey/Kreyenfeld et al. (2010), 2002-2007 Kreyenfeld et al. (2010), 2008 combination Kreyenfeld et al. (2010)/ official statistics (all births); total TFR ${ }^{*}$ calculated from TFR ${ }^{*}+\mathrm{TFR}_{2}{ }^{*}+\mathrm{TFR}_{3}{ }^{*}+\mathrm{TFR}_{4+}$ (see section on data and methods). 


\section{Comparative Population Studies - Zeitschrift für Bevölkerungswissenschaft}

www.comparativepopulationstudies.de

ISSN: 1869-8980 (Print) - 1869-8999 (Internet)

Published by / Herausgegeben von

Prof. Dr. Norbert F. Schneider

Layout and print: Federal Institute for Population Research, Wiesbaden (Germany)

Managing Editor / Redaktion

Frank Swiaczny

\section{Copy Editor / Schlussredaktion}

Dr. Evelyn Grünheid

\section{Scientific Advisory Board / Wissenschaftlicher Beirat}

Jürgen Dorbritz (Wiesbaden)

Paul Gans (Mannheim)

Johannes Huinink (Bremen)

Marc Luy (Wien)

Clara H. Mulder (Groningen)

Notburga Ott (Bochum)

Peter Preisendörfer (Mainz)

\section{Board of Reviewers / Gutachterbeirat}

Martin Abraham (Erlangen)

Laura Bernardi (Lausanne)

Hansjörg Bucher (Bonn)

Claudia Diehl (Göttingen)

Andreas Diekmann (Zürich)

Gabriele Doblhammer-Reiter (Rostock)

Henriette Engelhardt-Wölfler (Bamberg)

E.-Jürgen Flöthmann (Bielefeld)

Alexia Fürnkranz-Prskawetz (Wien)

Beat Fux (Zürich)

Joshua Goldstein (Rostock)

Karsten Hank (Mannheim)

Sonja Haug (Regensburg)

Franz-Josef Kemper (Berlin)

Michaela Kreyenfeld (Rostock)

Aart C. Liefbroer (Den Haag)

Kurt Lüscher (Konstanz)

Dimiter Philipov (Wien)

Tomáš Sobotka (Wien)

Heike Trappe (Rostock) 